\title{
Toll-like Receptors from the Perspective of Cancer Treatment
}

\author{
Nasir Javaid and Sangdun Choi * \\ Department of Molecular Science and Technology, Ajou University, Suwon 16499, Korea; \\ nasirjavaid1989@gmail.com \\ * Correspondence: sangdunchoi@ajou.ac.kr; Tel.: +82-31-219-2600
}

Received: 8 January 2020; Accepted: 25 January 2020; Published: 27 January 2020

\begin{abstract}
Toll-like receptors (TLRs) represent a family of pattern recognition receptors that recognize certain pathogen-associated molecular patterns and damage-associated molecular patterns. TLRs are highly interesting to researchers including immunologists because of the involvement in various diseases including cancers, allergies, autoimmunity, infections, and inflammation. After ligand engagement, TLRs trigger multiple signaling pathways involving nuclear factor- $\mathrm{kB}(\mathrm{NF}-\mathrm{kB})$, interferon-regulatory factors (IRFs), and mitogen-activated protein kinases (MAPKs) for the production of various cytokines that play an important role in diseases like cancer. TLR activation in immune as well as cancer cells may prevent the formation and growth of a tumor. Nonetheless, under certain conditions, either hyperactivation or hypoactivation of TLRs supports the survival and metastasis of a tumor. Therefore, the design of TLR-targeting agonists as well as antagonists is a promising immunotherapeutic approach to cancer. In this review, we mainly describe TLRs, their involvement in cancer, and their promising properties for anticancer drug discovery.
\end{abstract}

Keywords: toll-like receptor; pathogen-associated molecular pattern; cytokine; cancer; anticancer drug

\section{Introduction}

Toll-like receptors (TLRs) belong to the family of pathogen recognition receptors (PRRs) in the innate immune system and recognize pathogen-associated molecular patterns (PAMPs) and damage-associated molecular patterns (DAMPs) related to foreign invading pathogens and host cells, respectively. To date, 13 TLRs have been reported in mice and 10 in humans, which are expressed on various immune cells (dendritic cells (DCs), macrophages, T-cell subsets, and B cells) and nonimmune cells (epithelial cells and fibroblasts) in humans. Based on their subcellular localization in humans, TLRs can be subdivided into two main groups: TLRs 1, 2, 4, 5, and 6 are present on the plasma membrane of cells; in contrast, TLRs 3, 7, 8, and 9 are localized in the endosomal membrane [1]. Each type of TLR recognizes its specific ligand(s) and activates the associated signaling pathway in either a myeloid differentiation primary response protein 88 (MyD88)- or TIR domain-containing adaptor inducing IFN $\beta$ (TRIF)-dependent manner. The activation of signaling leads to the secretion of various cytokines, which help the host body to combat various invaders. Furthermore, TLRs are responsible for maturation of DCs, which link innate and adaptive immune responses [2].

TLRs belong to the class of integral membrane type I glycoproteins, which have three major domains: the extracellular domain with different numbers of leucine-rich repeat (LRR) motifs, the transmembrane domain, and the cytoplasmic domain (similar to that of interleukin-1 receptor; IL-1R), which is known as the Toll/IL-1R (TIR) domain [3]. The extracellular domain has 19-25 tandem LRR motifs (20-26 in case of mammals), and each one of them contains 24-29 amino acid residues, including conserved residues (XØXXØXXXXFXXLX; Ø = hydrophobic residue) as well as motif XLXXLXLXX. 
Each LRR motif forms an $\alpha$-helix and $\beta$-strand separated by a loop, which eventually forms a horseshoe structure after ligand binding on its inner concave surface in most of TLRs except TLR3, where the ligand binds to the outer convex surface [4].

Upon ligand recognition, TLRs undergo conformational changes to form homo- or heterodimers, which induce their TIR domain to interact with the TIR domain of intracellular adaptor molecules including MyD88, TIR domain-containing adaptor protein (TIRAP, i.e., Mal), TRIF, i.e., TICAM1, and TRIF-related adaptor molecule (TRAM, i.e., TICAM2) [5]. The details of this signaling pathway are described elsewhere [6]. Briefly, relevant adaptor molecules recruit various members of the interleukin 1 receptor-associated kinase (IRAK) family, in turn activating tumor necrosis factor receptor-associated factor 6 (TRAF6), whose ubiquitination switches on transforming growth factor $\beta$ (TGF- $\beta$ )-activated protein kinase 1 (TAK1). The latter causes the inhibitor of $\kappa B$ kinase (IKK) complex to stimulate the activity of a transcription factor (nuclear factor kappa-light-chain enhancer of activated B cells; NF- $\mathrm{kB}$ ) and various mitogen-activated protein kinases (MAPKs) to trigger c-Jun N-terminal kinase (JNK), protein 38 (p38), and extracellular signal-regulated kinase (ERK), which turns on a transcription factor called activated protein 1 (AP-1) [7]. TLR3 and TLR4 employ TRIF/TRAM adaptor molecules to launch the activity of interferon response factor (IRF) 3, whereas TLR7, TLR8, and TLR9 activate IRF7. These transcription factors move into the nucleus and initiate the expression of various target genes including inflammatory cytokines, chemokines, and type I interferons (IFNs).

Cancer cells divide uncontrollably unlike the 200 types of somatic cells in our body, which can double 50-60 times before entering the state of senescence [8]. The cancer hallmarks include tumor metastasis and angiogenesis and tumor cell survival and proliferation [9]. The conversion to malignancy and cancer progression involve downregulation of tumor suppressor genes and upregulation of proto-oncogenes and associated signaling pathways $[9,10]$. Moreover, several cellular and molecular mechanisms help tumors escape the body's own natural immune response [11,12]. The importance of immune regulation for cancer progression can be explained by the presence of increased amounts of immunosuppressive factors and cells and by scarcity of immune-system-activating signals in a tumor microenvironment. Under this scenario, it is worthwhile to activate immune cells through the receptors on their surfaces; one of these receptors is a TLR. Its activation is a double-edged sword, i.e., the exact pro- or antitumor effect depends upon the type of TLR, the cell type expressing it, and the downstream signaling cascade in such cells. For anticancer therapies, TLR agonists are being explored as vaccine adjuvants for the stimulation of immune cells and promotion of inflammation. TLR activity also upregulates the expression of such costimulatory molecules as CD40, CD80 (B7.1), and CD86 (B7.2) and cytokines like IL-12, which stimulates other immune cells like T lymphocytes [2,13]. In contrast, TLR expression and triggering on other cells including cancer cells can lead to tumor growth [14]. Active TLR signaling regulates the expression of various genes involved in tumor progression (Figure 1). Here, we review the roles of TLRs and their downstream pathways in cancer in relation to therapeutic interventions. 


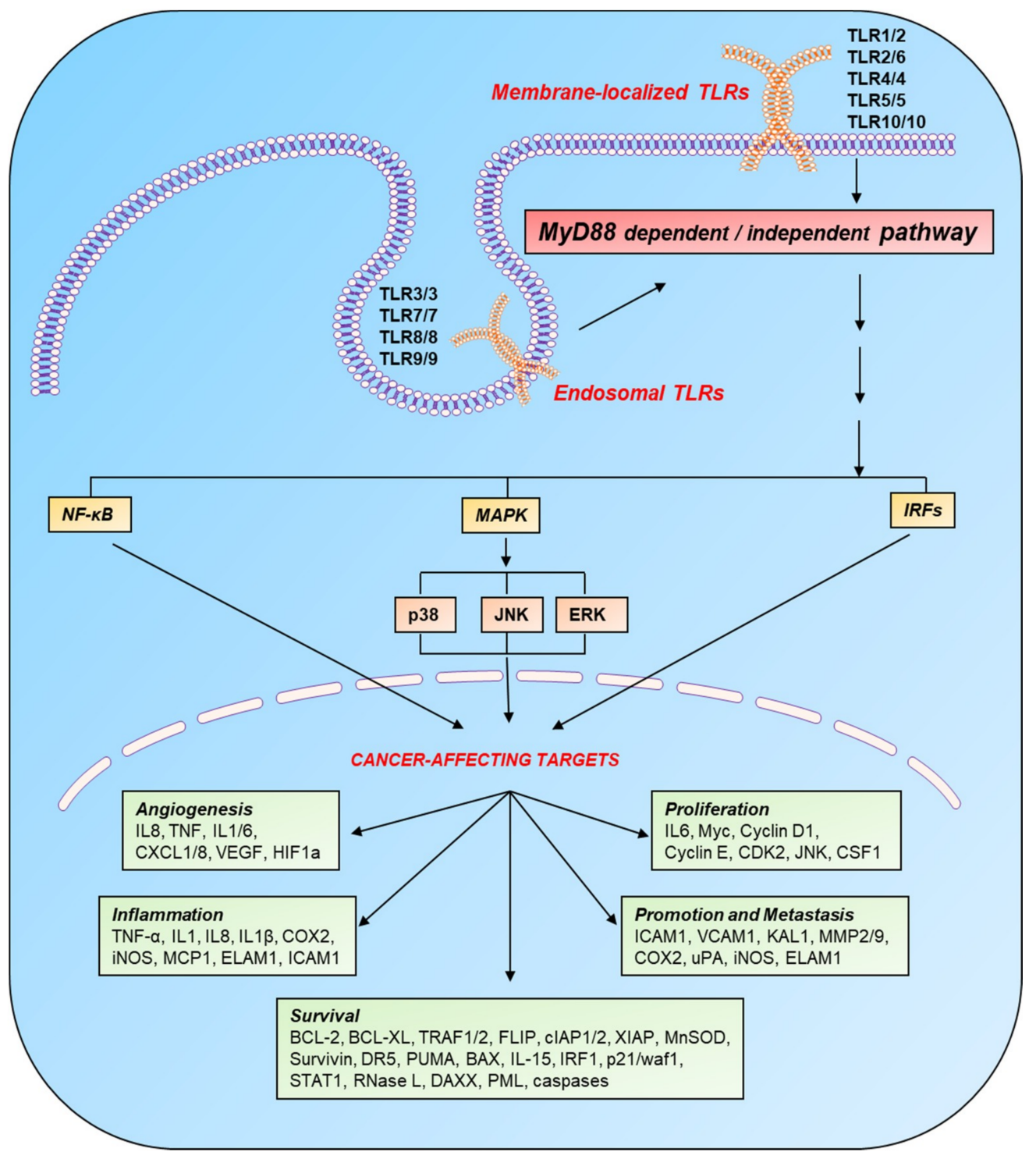

Figure 1. Induction of cancer-affecting genes by TLR signaling. TLRs are localized on the cell surface and in the endosomal compartment and become active after recognizing their respective PAMPS and DAMPs. On the basis of intracellular adaptor molecules, TLR pathways are categorized into two main cascades: MyD88-dependent and MyD88-independent. These pathways switch on various transcription factors: p50/p65, AP-1, and IRFs through NF-kB, MAPK, and IFN pathways, respectively. These transcription factors target various genes (involved in the processes of inflammation, angiogenesis, cell survival, proliferation, and metastasis), which directly or indirectly affect the progression of cancer. Legend: AP-1, activated protein 1; BAX, BCL2-associated X; BCL, B-cell lymphoma protein; CDK, cyclin-dependent kinase; cIAP, cellular inhibitor of apoptosis protein; COX, cyclooxygenase; CSF, colony-stimulating factor; CXCL, chemokine (C-X-C motif) ligand; DAXX, death domain-associated protein; DR, death receptor; ELAM, endothelial-leukocyte adhesion molecule; ERK, extracellular signal-regulated kinase; FLIP, FLICE-like inhibitory protein; HIF, hypoxia-inducible factor; ICAM, intercellular adhesion molecule; IFN, interferon; IL, interleukin; iNOS, inducible NO synthase; IRF, interferon response factor; JNK, c-Jun N-terminal kinase; KAL, Kallmann syndrome gene; MAPK, mitogen-activated protein kinase; $\mathrm{MCP}$, monocyte chemoattractant protein; MMP, matrix metalloproteinase; MnSOD, manganese superoxide dismutase; MyD88, myeloid differentiation primary response 88; NF- $\mathrm{kB}$, nuclear factor кB; p38, protein 38; PML, promyelocytic leukemia protein; PUMA, p53-upregulated modulator of apoptosis; STAT, signal transducer and activator of transcription; TLR, Toll-like receptor; TNF- $\alpha$, tumor necrosis factor $\alpha$; TRAF, tumor necrosis factor receptor (TNF-R)-associated factor; uPA, urokinase-type plasminogen activator; VCAM, vascular cell adhesion molecule; VEGF, vascular endothelial growth factor; WAF, wild-type activating fragment; XIAP, x-linked inhibitor of apoptosis protein. 


\section{The NF- $\kappa$ B Pathway}

The NF-kB family consists of five transcription factors-RelA (p65), RelB, c-Rel, p50 (fragment of p105) (NF-kB1), and p52 (fragment of p100) (NF-kB2) — which bind to the promoter region of their target genes in the form of homodimers or heterodimers. Stimulation of NF- $\mathrm{kB}$ is performed by various factors, e.g., cytokines (IL-1 $\beta$, TNF- $\alpha$ ), viral and bacterial products [dsRNA, lipopolysaccharide (LPS)], growth factors [epidermal growth factor (EGF)], reactive oxygen species (ROS), ionizing and UV radiation, and DNA damage stress from the affected cells. All these stimuli activate the inhibitor of $\mathrm{kB}$ (IKB) complex, which consists of three key components: NF-kappa-B essential modulator (NEMO) such as IKK $\gamma$, IKK1 (i.e., IKK $\alpha$ ), and IKK2 (also known as IKK $\beta$ ). Active IKK phosphorylates IKB at serines 32 and 36 for further processing.

The SCF- $\beta \operatorname{TrCP}$ E3 ligase (Skp1-Cul1-F-box ligase containing the F-box protein $\beta \operatorname{TrCP}$ ) [15] and $\mathrm{E} 2$ of the Ubc4/5 family [16] take part in the ubiquitination of IкB. Two $\beta$-transducin repeat-containing proteins $(\beta$-TrCP), i.e., $\beta$-TrCP1 and $\beta$-TrCP2, have been discovered in mammalian cells. Their WD40 repeats at the $C$ terminus interact with phosphorylated IкB, while the F-box interacts with the Skp, Cullin, F-box containing complex (SCF) complex containing Roc1/Rbx1 (RING domain protein), which interacts with $\mathrm{E} 2$ of $\mathrm{Ubc} 4 / 5$ allowing I $\mathrm{B}$ ubiquitination on the two conserved lysine residues at its $\mathrm{N}$ terminus. This ubiquitinated I $\kappa B$ stays associated with NF- $\kappa B$ followed by selective degradation by the $26 \mathrm{~S}$ proteasome, which eventually releases the NF- $\mathrm{kB}$ [17]. The released dimers relocate to the nucleus for induction of target genes.

NF-KB activation involves canonical (classic), non-canonical (non-classic), and alternative (atypical) pathways. The major pathway is the canonical one in most of cell types and involves p65, p50, and c-Rel. The pathway itself consists of IKK, IKB, and NF- $\mathrm{B}$, which is switched on by TLRs or other PRRs, proinflammatory cytokines (e.g., TNF- $\alpha$ and IL-1 $\beta$ ), or cellular stressors [18]. It can also be triggered by DNA-damaging agents like etoposide, camptothecin, adriamycin, and ionizing radiation. IKK $\gamma$ is phosphorylated by a sensor of DNA damage called ataxia telangiectasia mutated (ATM) and is recruited for the formation of the PIDDosome in the nucleus. Upon activation by ATM, NEMO moves to the cytoplasm and binds to IKK $\beta$, which induces IKB degradation and launches the canonical pathway [19-22]. The non-canonical pathway includes TNF receptor family members such as B-cell-activating factor (BAF), lymphotoxin beta (LT $\beta), C D 40$, and viral proteins. This cascade involves NF- $K B$-inducing kinase (NIK)-dependent activation of IKK $\alpha$ with subsequent formation of p50 by the cleavage of p100. This p52 and RelB are translocated to the nucleus in the form of a functional complex and induce the expression of target genes [18,23]. Mediators of the atypical pathway (such as UV light of short wavelength) make NF- $\mathrm{KB}$ active in an IKK-independent manner by initiating IкB phosphorylation and degradation by casein kinase 2 (CK2) and calpain, respectively [24]. Similarly, hydrogen peroxide-mediated activation of NF- $\mathrm{KB}$ involves IKB phosphorylation at Tyr24 by the c-Src or Syk kinase $[25,26]$.

NF-KB plays various roles by regulating transcription, apoptosis, and cell proliferation. It controls transcription mostly by acting as an inducer, with some exceptions. It induces $\sim 200$ genes involved in various functions like inflammation, immune responses, and growth [27]. Conversely, it suppresses the expression of certain genes when it is turned on by DNA-damaging drugs [28]. This suppressive behavior is cell line dependent and could occur after interaction with tumor suppressors or transcriptional repressors, e.g., ARF or p53 [29,30]. NF-kB regulates apoptosis by targeting some antiapoptotic proteins such as TRAF1, TRAF2, cIAP-1, cIAP-2, Bcl-xL, MnSOD, XIAP, and IEX-1L [31]. It can act as a proapoptotic factor by inducing the expression of mediators involved in apoptosis such as FAS ligand, death receptor DR5, Bax, and PUMA [32-34]. NF- $\mathrm{kB}$ regulates cell proliferation by transactivating the expression of c-Myc and cyclin D1. Of note, inflammation- and proliferation-triggering cytokines (such as TNF- $\alpha$, IL-8, and IL-1 $\beta$ ) are also expressed as a result of NF- $\mathrm{kB}$ activation [31]. Nonetheless, NF- $\mathrm{kB}$ can inhibit cell proliferation by suppressing JNK (a proliferation factor) and upregulating p21 (also known as WAF1; a cell cycle suppressor) [27]. 
Genes involved in cell survival and cell proliferation are known to be modulated by NF-kB [35]. Disruption of NF-kB-encoding and IkB-encoding genes owing to cancer-associated mutations, deletions, and chromosomal translocations might uncouple NF- $\mathrm{kB}$ from its regulators to make it constitutively active [36]. Constitutively activated NF- $\mathrm{kB}$ leads to cancer initiation via either cell proliferation or apoptosis inhibition through several mechanisms $[37,38]$. These involve transcriptional regulation of apoptosis-inhibiting proteins, e.g., XIAP, cIAPs, Bcl-2, and Bcl-xL $[39,40]$. NF- $\mathrm{kB}$ participates in protumor inflammation by means of certain cytokines, e.g., IL-1, TNF- $\alpha$, and IL- 6 as well as COX2, MCP1, and iNOS. Some of the target genes cause epithelial-mesenchymal transition (Twist, vimentin), angiogenesis-mediated remodeling of the extracellular matrix (IL-8, VEGF), and enhancement of metastasis and invasion (uPA, MMP2, and MMP9) [41]. Besides, NF- $\mathrm{BB}$ targets cyclin-coding genes such as cyclins G1, D1, and E [42,43].

\section{The MAPK Pathway}

The evolutionarily conserved MAPK pathway responds to extracellular signals and controls vital cellular processes including proliferation, growth, differentiation, apoptosis, and migration. Diverse stimuli trigger multiple MAPK pathways in a well-coordinated and integrated manner. These stimuli include growth factors, hormones, cytokines, TGF- $\beta$-associated agents, agents related to G protein-coupled receptors, environmental stress, DAMPs, and PAMPs. These pathways involve three kinase components: activation of MAPK results from its phosphorylation by MAPK kinase (MAPKK), and activation of MAPKK results from its phosphorylation by MAPKK kinase (MAPKKK). This phosphorylation affects Tyr and Thr residues of the Thr-X-Tyr motif in the activation loop of kinase subdomain VIII [44]. In mammals, six unique MAPK groups have been described: Jun N-terminal kinase (JNK) $1 / 2 / 3$, p38 isoforms $\alpha / \beta / \gamma$ (ERK6)/ $\delta$, extracellular signal-regulated kinase (ERK) $1 / 2$, ERK3/4, ERK5, and ERK7/8 [45,46]. Cells undergo tumorigenesis as a consequence of one or more processes: apoptosis evasion, independence from proliferative signals, continuous replication, non-responsiveness to antigrowth signals, invasion, metastasis, sustainability of angiogenesis, drug resistance, and evasion of oncogene-induced senescence [9]. These processes are triggered by abnormalities in MAPK signaling, which lead to cancer initiation and progression.

\subsection{ERKS}

Multiple MAPK pathways along with NF-KB are activated by inflammatory and stressful stimuli instead of mitogens. That is why they are promising drug targets in case of inflammation. Among all mammalian MAPKs, ERKs were the first to be identified. They are mostly considered mitogenand insulin-activated MAPKs that are recruited by Ras-activating agonists. Ras next interacts with a protein of the Raf family, which switches on two MAP2Ks (MEK1 and MEK2). Detailed regulation and biology of the activation of Ras-dependent ERKs are reviewed elsewhere [47,48].

In many cases, the activation of ERKs is independent of Ras, but not when they are triggered by proinflammatory stimuli such as a cytokine (e.g., from the TNF family), a PAMP (e.g., lipopolysaccharides of invading pathogens), or a DAMP (e.g., oxidized low-density lipoprotein). PAMPs or DAMPs interact with PRRs (including TLRs) to turn on the ERK pathway that plays an important role in inflammation and innate immunity. Two genes, Erk1 and Erk2, encode ERKs. These ERKs undergo dual phosphorylation at Tyr and Thr residues of subdomain VIII: Thr203-Glu-Tyr205 (ERK1) or Thr185-Glu-Tyr187 (ERK2) [48].

Several nuclear and cytoplasmic targets including phosphatases, kinases, cytoskeletal proteins, and transcription factors are phosphorylated by active ERKs [49]. Depending on the cell type, such processes as differentiation, chromatin remodeling, proliferation, migration, cell survival, and angiogenesis are regulated by ERK signaling [49,50]. Organized execution of these diverse processes by ERKs is based on differential expression and phosphorylation of their early targets like Jun, Fos, Egr-1, and Myc [51]. Continuous stimulation of ERK signaling promotes entry into the cell cycle via phosphorylation and stabilization of the above-mentioned targets as well as upregulation of 
genes needed for cell cycle entry (e.g., cyclin D1) and downregulation of antiproliferative genes [52]. Conversely, strong ERK signaling can induce the expression of p21 and p27 (CDK inhibitor proteins), which can cause cell cycle arrest [53]. Tumor cells counteract ERK-mediated stimulation of CDK inhibitor proteins by making AKT pathways constitutively active or by enhancing Rho signaling $[53,54]$. Additionally, ERK signaling promotes cell proliferation by counteracting the effect of TGF- $\beta$ and other similar ligands. Nevertheless, various negative feedback loops maintain the balance between ERK activation and deactivation, whose deregulation may result in the initiation of cancer $[55,56]$.

\subsection{JNKS}

JNKs were first reported as protein kinases in a cycloheximide-treated rat liver. These enzymes can phosphorylate Ser63 and Ser73 residues of transcription factor c-Jun; these residues are important for regulation of the transactivating function of AP-1 and c-Jun [57]. They are activated by mitogens, environmental stressors (oxidants, ionizing radiation, and heat shock), ischemia-reperfusion injury, genotoxins (alkylating agents and topoisomerase inhibitors), vasoactive peptides, mechanical shear stress, PAMPs, DAMPs, and proinflammatory cytokines [58-60]. Tunicamycin is an inhibitor of N-linked protein glycosylation and thereby stimulates JNKs. The reason is endoplasmic reticulum (ER) stress caused by the accumulation of misfolded proteins within the ER lumen. This observation indicates effective association of JNKs with ER stress, which can also be triggered by a high-fat diet leading to inflammation and insulin resistance.

Three genes, Jnk1-3 (also known as Mapk8-10, respectively), encode JNKs; among them, Jnk1 and $J n k 2$ are ubiquitous, whereas $J n k 3$ is limited to the heart, brain, and testes $[58,59,61]$. The expression of these genes is subject to differential heterogeneous-nuclear-RNA splicing affecting (1) the catalytic domain extending to subdomains IX and X (to generate $\alpha$ and $\beta$ JNKs, respectively) and (2) the terminal $\mathrm{COOH}$ region thus giving rise to 46 and $54 \mathrm{kDa}$ polypeptides (named type 1 and type $2 \mathrm{JNKs}$ ), which might generate $12 \mathrm{JNK}$ polypeptides. Each of these isoforms possesses the Thr-X-Tyr phosphoacceptor motif in its kinase subdomain VIII just as other MAPKs do; however, the sequence is Thr183-Pro-Tyr185 for JNKs. The $\alpha$ and $\beta$ JNKs show slight variation in affinity for their substrates $[58,60,62,63]$.

JNK activity and phosphorylated c-Jun play a major role in Ras-mediated tumorigenesis, and c-Jun and Ras cooperate for cellular transformation [64]. The phosphorylation site in c-Jun is the same for both Ras and JNK; therefore, Ras-mediated transformation is not observed in c-Jun-deficient fibroblasts [65]. It has also been reported that c-Jun can downregulate the $p 53$ gene [66]. Nonetheless, studies on JNK1/2-null cells have revealed that Ras-mediated transformation and tumorigenesis are independent of these two kinases. On the contrary, a JNK might promote apoptosis because of a tumor-suppressive function [67]. After exposure of cells to genotoxic drugs, JNK inhibitors impede DNA repair; hence, they can be employed for cancer therapy [68]. Nevertheless, their usefulness is not clear because of their ability to prevent apoptosis. The activation of NF-KB along with a JNK reverses the effect of the JNK because the former competitively inhibits the oncogene-induced apoptosis caused by the latter [69]. The reason is probably NF-kB-mediated induction of genes whose products repress JNK activity [70]. Therefore, apoptosis can be promoted in a JNK-dependent manner via inhibition of NF- $K B$ activity.

\section{3. $p 38$}

The first isoform of p38 (p38 $\alpha$ ) was isolated using antiphosphotyrosine beads from the extracts of cells treated with endotoxin. Sequencing revealed its resemblance to osmosensing MAPK HOG1 from Streptomyces cerevisiae in terms of its phosphoacceptor motif Thr-Gly-Tyr [71,72]. Furthermore, it has been independently identified as an IL-1-activated and stress-activated kinase that can switch MK2 on after the phosphorylation of its particular element. MK2 (being a member of the Ser/Thr kinase family) in turn can make small heat shock protein Hsp27 active by phosphorylating it $[73,74]$.

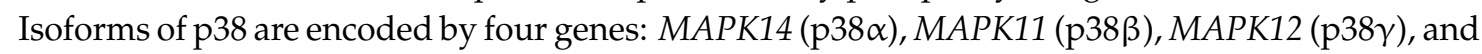
$M A P K 13$ (p388), which are effectively upregulated by inflammatory cytokines, environmental stress, 
PAMPs, and DAMPs [74-78]. The $\alpha$ isoform of $\mathrm{p} 38$ has been studied as an anti-inflammatory drug target of pyridinyl-imidazole compound SB203580 [78]. In vitro assays have revealed that SB203580 and its derivatives can inhibit only isoforms p38 $\alpha$ and $p 38 \beta$ because of the presence of the Thr106 residue in the pivot of the ATP-binding pocket in p38 $\alpha$ and p38 $\beta[75,79-81]$.

In addition to the stress response, the p38 pathway participates in cell cycle progression and regulation of apoptosis, differentiation, and growth. A possible explanation is its responsiveness to diverse stimuli such as hormones and growth factors (like fibroblast growth factor, GM-CSFD, nerve growth factor, PDGF, and insulin-like growth factor 1). These stimuli lead to the activation of various MAPKKKs such as ASK1/2, MEKK4, TAK1, TAO1/2/3, MLK2/3, and DLK [82].

The tumor-suppressive function of $\mathrm{p} 38$ has been revealed in mice with disrupted $\mathrm{p} 38 \alpha$ or both Mek3 and Mek6 $[83,84]$. The Ras-mediated transformation is also affected by the suppression of p38 activity [85]. p38 initiates p53-mediated apoptosis by acting as a negative regulator of cell cycle progression [86]. The oncogenic-stress-mediated induction of p38 in mouse embryonic fibroblasts has been reported to cause Ras-mediated senescence [87]. These findings point to the possibility of chemotherapeutic targeting of p38 for tumorigenesis suppression [88,89]. The inhibition of p38 enhances apoptosis after application of a DNA-damaging agent (such as cisplatin or doxorubicin) and a microtubule-disrupting agent (such as vinblastine, vincristine, or taxol) [90-92].

\section{The Type I IFN Pathway}

The IFN family, originally discovered as a group of antiviral agents, is now known to start various biological processes in a cell-dependent manner. Their antiviral efficiency varies $\sim 1000$-fold, and some weak IFNs (like IFN $\gamma$ ) inhibit proliferation of specialized cells but not proliferation of other cell types, where they regulate migration, differentiation, activation, and apoptosis, e.g., in all immune effector cells. IFNs are categorized into type I IFNs (more than 20 subtypes including $\alpha, \beta$, and $\varepsilon$ ), the single type II IFN $(\gamma)$, and three type III IFNs ( $\lambda$ subtypes) according to their sequence, stimuli, receptors, and affected cell types. Proliferative stimulation of natural killer (NK) cells and NK T cells by cytokines (such as IL-12) yields IFN $\gamma$ production. On the other hand, type I IFNs and IFN $\lambda$ s are produced as a result of viral infection. Despite differences, IFNs induce some common genes by triggering common pathways such as Janus kinase-signal transducers and activators of transcription (JAK-STAT). Among these IFNs, type I IFNs are exclusively induced by TLRs.

Type I IFNs belong to the class of the most diverse, evolutionarily conserved, and multigene cytokines of various subtypes. In humans, chromosome arm 9p contains a cluster of 30 types of IFN genes: 13 IFN $\alpha$ genes and single IFN $\beta, \omega, \kappa$, and $\varepsilon$ subtypes with 13 pseudogenes [93]. The IFN $\varepsilon$ gene has a specific expression pattern being silent in hematopoietic-origin tissues [93]. In humans and mice, IFNK is basically expressed by keratinocytes along with DCs and monocytes.

Most of IFN $\alpha$ s share 78-98\% identity, with 166 amino acid residues folded into five $\alpha$-helices with two disulfide bonds for stabilization. IFN $\beta$ and IFN $\varepsilon$ show almost $35 \%$ identity to the IFN $\alpha$ amino acid sequence. Human IFN $\alpha$ is only weakly glycosylated, in contrast to both IFN $\beta$ and murine IFN $\alpha$ s [94]. Most of type I IFNs are highly stable at $56^{\circ} \mathrm{C}$ and $\mathrm{pH} 2$ with isoelectric points of 5.6 and 8.9 for IFN $\alpha$ and IFN $\beta$, respectively [95]. To understand their pharmacokinetics, it is important to know their physicochemical properties. IFN $\alpha$ has somewhat higher stability (2-3 h half-life) in serum than IFN $\beta$ does; the latter is rarely detectable because of its hydrophobic nature even though it induces a response of the magnitude comparable to that of IFN $\alpha$. These properties suggest that IFN $\alpha$ may be more effective systemically, whereas IFN $\beta$ may be more effective locally by functioning in a paracrine or autocrine manner.

Type I IFNs perform a variety of functions: (1) They allow cells to combat a viral infection whose mechanism is cell- and virus-dependent. IFN-regulatory genes target various stages of viral replication such as entry, transcription, translation, maturation, assembly, and the final release. For example, viral RNA is degraded by host RNase L, which is activated by the $2^{\prime}$-to-5'-linked oligoadenylates produced by $2^{\prime}-5^{\prime}$ oligoadenylate synthetase in an IFN-dependent manner [96]. Similarly, translation and replication 
of a virus are blocked in an IFN-dependent manner by protein kinase R (PKR) and Mx proteins, respectively $[97,98]$. (2) IFNs play an antiproliferative role by affecting cell cycle regulators such as c-Myc [99] and the production of growth factors and their associated receptors [100]. The proliferation of bone marrow-derived macrophages is inhibited by IFN $\beta$ with the help of colony-stimulating factor 1 (CSF1) [101]. Type I IFNs inhibit myelopoiesis because greater numbers of circulating myeloid cells are observed in IFNAR1-null mice [102]. The influence on proliferation is actually cell type dependent because IFNs stimulate the survival and/or proliferation of memory $\mathrm{T}$ cells, the effect that might be mediated by IL-15 [103]. (3) Type I IFNs affect the expression of apoptosis/survival-regulating molecules such as IRF1, p21, OKR, STAT1, RNase L, DAXX, PML, caspases, TNF family members, BCL2 family members, and death-associated kinases [104-109]. (4) Type I IFNs participate in immunoregulation by affecting the cells of innate and adaptive immune systems. These IFNs enhance the survival and differentiation of T cells [110], immature myeloid DCs [111], and B cells [112] as well as in vitro and in vivo cytotoxicity, cell proliferation, and cell differentiation in an NK cell-mediated manner [113]. Additionally, IFNs control immune cells' recruitment at an inflammatory site by inducing chemokines and associated receptors such as CCL12 and CXCL10 [114,115].

\section{TLR Signaling in Immune and Cancer Cells}

The pro- or antitumor effect of TLR signaling is determined by the specific TLR being stimulated, the cell type with activated signaling, and a downstream signaling cascade in the activated cells. Various TLR agonists promote inflammation by activating immune cells and are currently tested in clinical trials of anticancer therapies as vaccine adjuvants. TLRs are expressed on many cell types in humans but are mainly detectable on DCs, monocytes, and mature macrophages [116]. Ligand engagement by TLRs on these cells causes overexpression of multiple membrane-bound costimulatory molecules like CD40, B7.1 (CD80), and B7.2 (CD86) along with cytokines needed for proper T-cell activation such as IL-12 [2,13]. Aside from TLR activation on antigen-presenting cells (APCs), TLR activation in other cells also plays a substantial part in tumor growth. For instance, tumor cells and $\mathrm{T}$ cells express various TLRs that are activated after recognition of their associated ligands $[14,117]$. Proper communication between immune and cancer cells via cytokines or costimulatory molecules exerts an antitumor effect (Figure 2).

Treatment of mouse models with TLR agonists lessens the growth of tumors and even destroys established tumors in some cases during a combinatorial therapy with other agents such as monoclonal antibodies, chemotherapy drugs, and antigenic vaccines, e.g., plasmid DNA, peptides, or proteins [118-123].

The expression profile of TLRs on T cells depends upon the T-cell subset in question as well as their activation status. Lower levels of TLR mRNA and protein are detected in naïve T cells and increase dramatically upon their stimulation via TCR or by such compounds as PMA or ionomycin [124]. Similarly, stand-alone activation of TLRs has a smaller effect on resting or naïve T cells, but TLRs exert costimulatory effects on T cells during the stimulation of TCR $[125,126]$. Nonetheless, TLR expression is transient and diminishes with the passage of time [124,125,127]. Notably, some TLRs are expressed more weakly in human and murine memory T cells than in activated T cells, but this level is enough for them to respond in the absence of triggering by TCR $[128,129]$. 


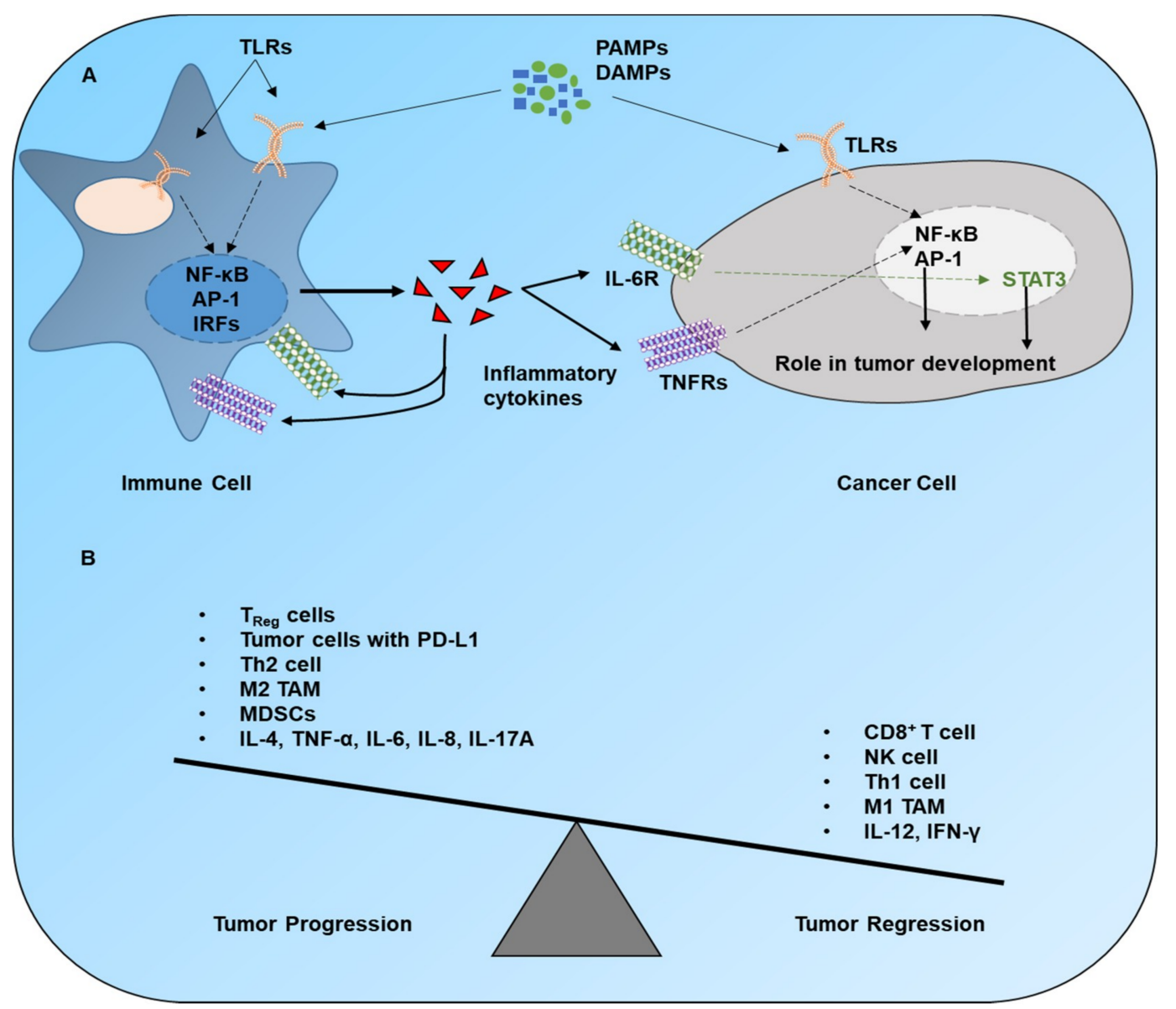

Figure 2. Immune regulation of cancer progression. (A) The stimulation of TLRs and other PRRs in immune cells launches downstream signaling pathways, which cause a release of various cytokines. These cytokines interact with their receptors on immune cells and cancer cells to trigger associated signaling pathways. The product(s) of these cascades plays a substantial role in the progression of cancer. (B) The overall outcome of cancer in a tumor microenvironment depends upon the ratio of protumor to antitumor signals. Legend: CD, cluster of differentiation; DAMPs, damage-associated molecular patterns; IFN, interferon; IL, interleukin; MDSCs, myeloid-derived suppressor cells; NK, natural killer; PAMPs, pathogen-associated molecular patterns; PD-L1, programmed-death ligand 1; TAM, tumor-associated macrophage; Th2, T helper type 2; TNF- $\alpha$, tumor necrosis factor $\alpha$; Treg, $\mathrm{T}$ regulatory.

\subsection{TLR Signaling in DC Subsets}

In the immune system, DCs are considered most efficient professional APCs. Immature DCs undergo infection- or inflammation-mediated activation and differentiation into mature DCs that activate the cells of adaptive immunity such as B and T lymphocytes [130]. The maturation of DCs involves a series of steps such as reduced changes in the sets of receptors of endocytosis and phagocytosis; overexpression of costimulatory molecules including CD40, CD58, and CD86; morphological changes; and reshuffling of lysosomal and MHC compartments. The DC population is a heterogeneous collection of various subtypes that differ in their function, phenotype, and localization. Two main populations are found in peripheral human blood, which include CD11c-negative plasmacytoid DCs (pDCs), CD11c-positive myeloid DCs (mDCs), monocyte-derived DCs (moDCs), and CD34 ${ }^{+}$cell-derived DCs [131]. These subsets express distinctive PRRs, which allow them to perform specialized functions by detecting different pathogenic stimuli. DCs take up pathogens and present pathogen-derived processed peptides to $\mathrm{T}$ cells by means of major histocompatibility complex (MHC) molecules. The activation status of DCs determines the overall outcome of an immune response. For example, resting 
DCs or those receiving inhibitory signals (such as corticosteroids or IL-10) promote immune tolerance by inducing upregulation of regulatory $\mathrm{T}\left(\mathrm{T}_{\text {reg }}\right)$ cells or elimination of effector $\mathrm{T}$ cells; however, mature DCs evoke immunity. $T$ cells are activated after recognition of the peptides processed and expressed by DCs (signal 1) and stimulation by cytokines (signal 2) and costimulatory molecules (signal 3).

TLR expression on DCs depends upon subtypes, species, and maturation stage. All three subpopulations of $\mathrm{mDC}$ (i.e., $\mathrm{CD} 1 \mathrm{c}^{-} \mathrm{mDCs}, \mathrm{CD} 16^{-} \mathrm{mDCs}$, and $\mathrm{BDCA3}^{-} \mathrm{mDCs}$ ) express TLRs $1-10$ except TLR3 (absent only in CD16 ${ }^{-} \mathrm{mDCs}$ ) at the RNA level. Both $\mathrm{CD} 1 \mathrm{c}^{-} \mathrm{mDCs}$ and $\mathrm{CD} 16^{-} \mathrm{mDCs}$ respond strongly to agonists of all TLRs except agonists of TLR9 (CPG oligodeoxynucleotides) [132]. Of note, $\mathrm{Cd} 16^{-}$mDCs respond to the TLR3 ligand poly(I:C) despite the absence of TLR3 RNA, in a TLR3-independent manner, possibly because of either cytosolic RNA sensors [133] or minor contamination with endotoxins. The $\mathrm{CD} 1 \mathrm{c}^{-} \mathrm{mDC}$ and moDCs both express similar endosomal (TLR3 and TLR8) and extracellular TLRs (TLRs 1, 2, 4, 5, and 6), which allow them to produce inflammatory cytokines after stimulation by the respective ligands [134,135]. Nonetheless, both subsets do not express TLR9, whereas TLR10 is expressed only by mDCs $[135,136]$. On the other hand, pDCs express TLR1 weakly, which is nonresponsive to the ligand of TLR1/2 owing to the absence of TLR2 [135]. Despite the absence of TLR3 and TLR8 expression, pDCs respond to viral pathogens, probably via TLR7, which binds to the same ligand and shares the signaling pathway. In addition, pDCs express TLR10 whose binding partner and function are still unknown $[137,138]$.

The distinct profile of TLRs in various subsets indicates that mDCs mainly respond to fungal and bacterial antigens, whereas pDCs mainly respond to viral pathogens. These subsets can be used in DC vaccination therapy for an antitumor and Th1 response $[136,139,140]$. Human pDCs can infiltrate various tumors such as ovarian cancer [141], head and neck cancer [142], and breast cancer [143]. The differentiation and maturation of infiltrating $\mathrm{pDCs}$ are prevented by the suppressive environment created by soluble factors secreted from a tumor [144-146]. Despite infiltration, pDCs cannot become activated after sensing DNA at the site of infiltration. These phenomena lead to the induction of $\mathrm{T}_{\text {reg }}$ cells and a poor prognosis $[143,147]$. Other studies have revealed that the recruitment of $\mathrm{pDCs}$ and the production of type I IFNs can be enhanced by a TLR7 agonist (imiquimod), which causes tumor regression by creating an inflammatory environment $[148,149]$. Similarly, an antitumor response has been observed in melanoma skin metastases and basal cell carcinoma after pDC activation by intratumoral injection of a TLR9 agonist, a CpG oligodeoxynucleotide [150]. This agonist will activate only pDCs because of the absence of TLR9 on mDCs. By contrast, a TLR7/8 ligand (R848) can stimulate both $\mathrm{pDCs}$ and $\mathrm{mDCs}$, and this approach will be more effective in eliciting an antitumor response at the tumor site.

Recent studies showed a cooperative and synergistic association between $\mathrm{mDC}$ and $\mathrm{pDC}$. Along with direct induction of a CD8 ${ }^{+}$T-cell response specific to a tumor antigen, pDCs stimulate the tumor antigen-presenting ability of mDCs toward T cells [151]. Moreover, both of these human DC subsets stimulate each other when any of them is activated in vitro by its respective TLR ligand [152]. In clinical settings, the research in this field suggests that $\mathrm{DC}$ vaccination with both $\mathrm{mDCs}$ and $\mathrm{pDCs}$ is more effective than vaccination with moDCs alone in terms of an antitumor response [152].

\subsection{TLR Signaling in T-Cell Subsets}

\subsubsection{TLR1/2 and TLR2/6}

The functional engagement of TLR1/2 on CD8 ${ }^{+}$cells enhances the production of TNF- $\alpha[153,154]$, IFN $\gamma$ [155], and IL-2 [153] along with cytolytic molecules like perforin and granzyme B [156]. The importance of T-cell-mediated TLR signaling is emphasized by reversed or delayed tumor growth of B16 melanoma in tumor-bearing MyD88 knockout mice that received adoptive transfer of TCR-transgenic $\mathrm{CD}^{+}$pmel T cells, after peritumoral injections of Pam3CSK4 (a synthetic TLR2 agonist) [157]. In vitro and in vivo models have confirmed that a bacterial lipoprotein can kill tumor cells too by recruiting CD8 ${ }^{+}$cells $[158,159]$. 
Furthermore, the T-cell response is directly modulated by some DAMPs such as heat shock proteins. For example, $\mathrm{CD}_{4} \mathrm{RA}^{+}$naive and $\mathrm{CD} 45 \mathrm{RO}^{+}$memory $\mathrm{T}$ cells show reduced chemotaxis and increased $\beta 1$-integrin-dependent adhesion after downregulation of two chemokine receptors, CCR7 and CXCR4, because of Hsp60-mediated stimulation of TLR2 present on the surface of these cells [160]. The interactions between T cells and tumor cells or APCs are mediated by the presence of integrins on T cells, and these integrins strengthen the cell activation [161] and are considered the markers distinguishing between effector and memory T-cell subsets [162].

A durable and effective immune response is hindered by the tolerance and immune suppression caused by $\mathrm{T}_{\text {reg }}$ cells. The cytolytic activity of tumor-specific $\mathrm{CD} 8^{+} \mathrm{T}$ cells is compromised by the production of TGF- $\beta$ and IL-10. Moreover, the suppressive function of $T_{\text {reg }}$ cells is reduced by the stimulation of their TLR2 because $\mathrm{CD} 8^{+} \mathrm{T}$ cells proliferate when grown in coculture with $\mathrm{T}_{\text {reg }}$ cells treated with a bacterial lipoprotein [155]. Likewise, in in vitro and in vivo studies on murine $\mathrm{T}_{\text {reg }}$ cells, stimulated-TLR2-mediated reversal of the suppression is reported to be mediated by IL-2 and TCR activation [163-166].

Low-affinity tumor antigens cause insufficient stimulation of TCR signaling thereby posing another problem for the effective antitumor response of $\mathrm{T}$ cells $[167,168]$. Some other studies indicate formation of memory cells owing to weak TCR signaling after TLR1/2 activation on CD8 ${ }^{+}$cells $[128,157,169]$. Increased PKC and PI3K signaling activities cause costimulation of TLR signaling [170,171]. An increase in the expression of T-bet and its enhanced binding to the promoter regions of granzyme $\mathrm{B}$, IFN $\gamma$, and perforin genes is observed in $\mathrm{CD}^{+}$cells after TLR stimulation [156]. The importance of TCR activation is proven by the experiments showing that melanoma tumor growth is reduced by the injection of TCR-transgenic CD8 ${ }^{+}$pmel T cells and of the TLR2 ligand Pam3CSK4 into tumor-bearing MyD88 knockout mice; this phenomenon is not observed in the mice injected only with pmel T cells and MyD88 knockout pmel or TLR2 knockout pmel T cells [157]. Other studies have highlighted possible usefulness of lipopeptides as vaccines to generate a broad-spectrum T-cell repertoire via the triggering of TLR signaling in T cells [172]. Enhanced degranulation and IFN $\gamma$ production have been observed in $\gamma \delta$ T cells after TLR activation through TCR [173].

Increased levels of IFN $\gamma$ and IL-2 are observed in $\mathrm{CD}^{+}$and $\mathrm{CD}^{+} 5 \mathrm{RO}^{+}$cells after TLR2 stimulation $[126,153]$. Memory $\mathrm{CD} 4^{+} \mathrm{T}$ cells can be directly stimulated by TLR2-agonistic lipoproteins of Mycobacterium tuberculosis that cause enhanced proliferation and production of IFN $\gamma$ and IL-2. Along with TLR2 stimulation, these cells require associated TCR signaling for the proper response [174]. Moreover, TLR2 agonists increase the longevity of T cells through downregulation of proapoptotic proteins like Bim and upregulation of antiapoptotic proteins such as Bcl-xL and A1 [126,157].

\subsubsection{TLR3}

TLR3 is expressed by activated CD4 ${ }^{+} \mathrm{T}$ cells and enhances NF- $\mathrm{KB}-$ dependent cell survival and proliferation upon stimulation with a specific ligand, poly(I:C). The enhanced survival of cells is attributed to increased expression of antiapoptotic protein Bcl-xL [175]. It is reported that poly(I:C) can enhance the response and proliferation of $\mathrm{CD}^{+} \mathrm{T}$ cells independently of $\mathrm{CD} 4^{+} \mathrm{T}$ cells and APCs [158]. Moreover, the formation of memory T cells is enhanced by TLR3 costimulation via TCR; this phenomenon is attributed to the prolonged T-cell survival due to TLR3 signaling. In T cells, the ability of TLR3 signaling to obviate CD4- or APC-mediated costimulation and formation of memory T cells is a helpful feature for the design of cancer vaccines because costimulatory signals are absent in a tumor microenvironment [129].

Among $\mathrm{CD}^{+} \mathrm{T}$ cells of humans, IFN $\gamma$ production by PHA-activated memory or effector $\mathrm{T}$ cells rises after stimulation with poly(I:C) but fails to increase their lytic activity [176]. Similarly, proliferation of mouse $\mathrm{CD} 8^{+} \mathrm{T}$ cells and their secretion of IFN $\gamma$ were augmented after preincubation with antigen-pulsed splenocytes with poly(I:C). Unlike untreated CD8 ${ }^{+} \mathrm{T}$ cells, those treated with the TLR3 ligand showed a greater expansion potential upon adoptive transfer and displayed higher amounts of high-affinity CD25 (IL-2R $\alpha$-chain) and activation marker CD69 [177]. The enhanced 
expression of CD69 and increased production of IFN $\gamma$ have been observed in TLR3-stimulated freshly isolated $\gamma \delta \mathrm{T}$ cells [178]. In vitro, granzyme A-mediated and granzyme B-mediated cytolytic activities of an expanding $\gamma \delta \mathrm{T}$ cell population are augmented after TCR stimulation by bromohydrin pyrophosphate and pretreatment with poly(I:C) [179]. Along with IFN- $\gamma$, TLR3 activation in T-cells might also lead to the secretion of IFN- $\beta$ which plays a main role in antiviral response [180-182].

\subsubsection{TLR4}

The activation and greater proliferation of T cells under the influence of LPS are mediated by stimulation of the production of a cascade of proinflammatory cytokines by APCs [183]. LPS-induced TLR4 stimulation is also observed in $\mathrm{CD}^{+}$and $\mathrm{CD} 8^{+} \mathrm{T}$ cells that can produce TNF- $\alpha$, IFN $\gamma$, granzyme $B$, and perforin $[184,185]$. On the contrary, the expression of TLR4 and CD14 has not been detected in murine $\mathrm{CD}^{+} \mathrm{T}$ cells [185]. Nonetheless, murine naïve $\mathrm{CD}^{+} \mathrm{T}$ cells show increased survival and proliferation upon LPS treatment unlike nonresponsive naïve murine $\mathrm{T}$ cells [186]. Thorough analysis has revealed that TLR4 mRNA is expressed by the Th17 subset of murine CD4 ${ }^{+} \mathrm{T}$ cells and that LPS stimulation increases the level of IL-17A and reduces that of IFN $\gamma$ because of decreased activation of MAPK $[187,188]$. The activation of these cells by TLR4 can lead to colitis by aggravating intestinal inflammation.

LPS-induced activation of TLR4 in $\mathrm{CD} 4{ }^{+} \mathrm{CD} 25^{+} \mathrm{T}_{\text {reg }}$ cells enhances immunosuppressive activity and proliferation unlike the engagement of TLR1/2 [189]. On the other hand, HMGB1-induced triggering of TLR4 on $\mathrm{T}_{\text {reg }}$ cells reduces IL-10 production and the expression of forkhead box $\mathrm{p} 3$ and CTLA4 [171]. Furthermore, switched-on TLR4 in $\mathrm{T}_{\text {reg }}$ cells mainly launches signaling in a TRIF-dependent manner, but in nonregulatory T cells, this process is mediated by MyD88 and p38 MAPK [189]. These studies highlight the ligand- and cell-dependent response after TLR4 engagement.

\subsubsection{TLR5}

TLR5 binding by its ligand (bacterial flagellin)—similarly to other TLR agonists—leads to the production of IL-8, IL-10, and IFN $\gamma$ but not IL-4. The costimulatory effect of flagellin on effector memory $\mathrm{CD}^{+} \mathrm{CCR}^{-}$cells is stronger than the effect on CCR7 ${ }^{+}$central memory cells [190]. The induction of IFN $\gamma$ in the absence of IL-4 elicits a Th1 reaction that facilitates an efficient response of $\mathrm{CD}^{+} \mathrm{T}$ cells. The increased proliferation and production of TNF- $\alpha, \operatorname{IFN} \gamma$, and granzyme B under the influence of flagellin have also been observed in $\mathrm{CD} 8^{+} \mathrm{T}$ cells of human cord blood. This response is surprisingly stronger when it is implemented in combination with Pam3CSK4 (a TLR2 agonist) [190]. These synergistic effects of various TLR ligands highlight their usefulness in a combinatorial therapy designed to evoke an in vivo antitumor response of T cells. The activation of TLR5 on human $\mathrm{CD} 4{ }^{+} \mathrm{CD} 25^{+} \mathrm{T}_{\text {reg }}$ cells enhances the expansion of this subset with augmented suppressive activity in contrast to the inhibitory effects of other TLR agonists on murine $T_{\text {reg }}$ cells [191]. Nevertheless, it is necessary to confirm these results in vivo and elucidate the production of $\mathrm{T}_{\text {reg }}$ cell-inhibiting cytokines by macrophages and DCs.

\subsubsection{TLR7/8}

Human $\mathrm{T}_{\text {reg }}$ cells express TLR8, but naïve $\mathrm{CD} 4^{+} \mathrm{T}$ cells do not. A TLR9 ligand, CpG-A, induces the production of IFN $\alpha$ and IFN $\beta$, which facilitate the proliferation of effector $\mathrm{CD} 4^{+} \mathrm{T}$ cells by reversing the suppressive actions of $T_{\text {reg }}$ cells. Furthermore, an enhanced antitumor activity with a loss of suppressive activity by $T_{\text {reg }}$ cells is observed in a tumor mouse model upon their adoptive transfer after pretreatment with poly-G10 (a TLR8 ligand) [192]. Additionally, this study indicates that the TLR9 expressed on $\mathrm{T}_{\text {reg }}$ cells can recognize CpG DNA molecules too [192]. Similarly, TLR8 activation on human suppressor $\gamma \delta \mathrm{T}$ cells by ssRNA40 or poly-G3 reverses their in vivo and in vitro suppressive effects on $\mathrm{CD}^{+} \mathrm{T}$ cells [193]. The activation of TLR7/8 in human $\mathrm{CD} 4^{+} \mathrm{T}$ helper cells by its synthetic ligand such as resiquimod (R-848) increases the production of IL-10, IL-2, and IFN $\gamma$ with enhanced proliferation independent from APCs [190]. 


\subsubsection{TLR9}

The survival and antitumor response of $\mathrm{CD}^{+} \mathrm{T}$ cells are increased by TLR9 stimulation [164]. The increased in vitro survival of TLR9-activated murine T cells is explained by the initiation of NF- $\mathrm{KB}$ signaling and enhanced expression of antiapoptotic protein Bcl-XL [175]. It is reported that costimulation of T cells by a TLR9 ligand enables them to overcome their reliance on PKC- $\phi$ signaling and reverses their anergy status by re-establishing in vitro survival and proliferation [194]. Moreover, the activation of $\mathrm{CD} 4^{+} \mathrm{T}$ cells by a TLR9 ligand makes them resistant to the suppressive effect of $\mathrm{T}_{\text {reg }}$ cells [195]. Additionally, TLR9 engagement increases the number of $\mathrm{CD} 4^{+}$and $\mathrm{CD} 8^{+} \mathrm{T}$ cells by boosting the expression of IL-2 and of its associated receptor IL-12R, which takes place even in the absence of costimulatory molecules (such as CD28) in a tumor microenvironment [196]. A reduction in radiation-induced apoptosis and increased DNA repair are observed in TLR9-activated CD4 ${ }^{+} \mathrm{T}$ cells [197].

\subsection{TLR Signaling in the Cancer Cell}

TLRs are mainly expressed by immune cells such as macrophages, DCs, and T-cell subsets. Recent studies uncovered the expression of TLRs in various tumor cells [198-202]. For instance, the majority of colon cancer cells overexpress TLR2, TLR3, and TLR4 [203,204]. Similarly, ovarian cancer cells overexpress TLR2, TLR3, TLR4, and TLR5 [205,206].

Researchers are focusing on the expression and function of TLRs in various cancers. Enhanced invasiveness of human gastric cells and greater vascularization of gastric tissue after the activation of TLR2 enhance tumor growth by inducing the production of IL-8, PGE2, and COX-2 [207]. Higher mRNA copy numbers of TLR3 are observed in the colon mucosa of polyposis patients; this parameter is linked to the stages of colorectal cancer [208]. A reduction in the incidence, size, and number of neoplasms induced by chemicals has been observed in TLR4- and MyD88-deficient mice, thus underscoring a supportive role of TLR signaling in hepatocarcinogenesis $[159,209]$. The progression of human breast cancer is strengthened by the production of immunosuppressive factors (e.g., NO, IL-6, IL-12, VEGF, and MMPs) after the engagement of TLR4 by its ligand [210-212]. In mouse models of colon cancer, stimulation of TLR4 leads to the overexpression of an ICOS ligand (B7-H2) and programmed cell death ligand 1 (B7-H1) as well as downregulation of death receptor Fas; these changes prolong tumor survival [213]. The activation of TLR5 in human gastric cancers causes production of IL- 8 and TNF- $\alpha$, which lead to the proliferation of tumor cells [214]. The expression of TLR5 and TLR9 is significantly increased in late-stage cervical cancer but not observed in normal cervical squamous epithelial cells [215]. TLR7/8 activity enhances tumor growth, survival, metastasis, and inflammation in lung cancer patients [216]. TLR9 expression enhances angiogenesis, which is linked to lower survival rates of lung cancer patients [217]. Moreover, time- and dose-dependent proliferation of prostate cancer cells is observed during TLR9-mediated expression of NF-kB and c-Myc [218].

Although the incidence and progression of various tumors are promoted by TLRs, some TLRs may possess an antitumor function. Mycobacterium Bacillus Calmette-Guérin (BCG) is enriched with peptidoglycans and unmethylated CG-containing DNA, which stimulates TLR2, TLR4, and TLR9. Treatment with BCG reduces motility and proliferation and increases the apoptosis of cells of urothelial carcinomas [219]. Inhibition of proliferation and promotion of apoptosis of prostate cancer cells are observed after the activation of protein kinases by an agonist of TLR3, poly(I:C) [220]. Apoptosis of human colon cancer cells has been observed after combinatorial treatment with poly(I:C) and either IFN $\alpha$ or 5-fluorouracil [221]. Increased TLR3 expression in human melanoma cells after pretreatment with a type I IFN results in the inhibition of proliferation with subsequent death of these tumor cells [222]. The evidence of antitumor activity of TLR4 is scarce; however, its triggering on lung epithelial cells has a protective effect against the formation of a lung tumor [223].

TLR5 signaling in breast cancer downregulates cyclins B1, D1, and E2 thus inhibiting the proliferation of the tumor cells [224]. Increased apoptosis and decreased proliferation of head and neck cancer cells are seen after treatment with a TLR5 agonist, flagellin [225]. Cell cycle arrest and 
reduced proliferation of human glioma cells are reported after the launch of downstream NO and NF- $\mathrm{KB}$ pathways by a TLR9 agonist (CpG ODN 107) and irradiation [226]. Moreover, TLR9 activity enhances apoptosis of neuroblastoma cells and inhibits the angiogenesis in renal cell carcinoma [227].

In a word, cells of various cancer types express various TLRs. Among them, TLR3 and TLR5 have more promising antitumor effects unlike TLR4, $-7,-8$, and -9 . Of note, activation of a particular TLR on one type of tumor cells has an antitumor impact but may play a protumor role in another tumor type(s). Therefore, it is important to choose an optimal TLR agonist for tumor cells in question in order to ensure an antitumor effect. This choice should be based on the expression profile of TLRs and their functional outcome for this type of cancer.

\section{TLRs as Therapeutic Targets in Cancers}

The therapeutic targeting of TLRs in cancer has become more complicated with the discovery of protumorigenic activities of several TLRs in certain cancer types and the resultant clinical setbacks [228]. The activation of similar kinds of TLRs may have a protumor (Table 1) or antitumor (Table 2) effect in different types of cancers. To determine the effect on a tumor exactly, it is necessary to confirm suitable tumor types for immunotherapy, suitable TLRs to be targeted, and combinatorial options to enhance the immune response. Most of the relevant clinical trials have evaluated the agonists of TLR3, TLR7/8, and TLR9. Similarly, antagonists of TLR2 and TLR4 or their cognate ligands have shown antitumor properties.

Table 1. TLRs with a protumor effect.

\begin{tabular}{|c|c|c|c|c|c|}
\hline TLRs & Agonist/Ligand & Mechanism & Cancer Type & $\begin{array}{l}\text { Enhanced Cancer } \\
\text { Characteristics }\end{array}$ & References \\
\hline \multirow{7}{*}{ TLR2 } & Peptidoglycan (PGN) & $\begin{array}{l}\text { Synergistic effect of } \\
\text { wound-associated } \\
\text { injury and PGN }\end{array}$ & $\begin{array}{l}\text { Epithelial ovarian } \\
\text { cancer }\end{array}$ & $\begin{array}{l}\text { Self-renewal, } \\
\text { repair, and } \\
\text { recurrence }\end{array}$ & [229] \\
\hline & \multirow[t]{2}{*}{ Versican } & $\begin{array}{l}\text { Inflammatory } \\
\text { microenvironment }\end{array}$ & $\begin{array}{l}\text { Lewis lung } \\
\text { carcinoma }\end{array}$ & Metastasis & [230] \\
\hline & & $\begin{array}{l}\text { hCAP18/LL-37 } \\
\text { overexpression }\end{array}$ & Ovarian tumor & $\begin{array}{l}\text { Growth and } \\
\text { invasion }\end{array}$ & [231] \\
\hline & pg-LPS & $\begin{array}{l}\text { Increased NF- } k B \\
\text { signaling; IL-6, TGF- } \beta \text {, } \\
\text { VEGF, and MMP9 } \\
\text { secretion }\end{array}$ & $\begin{array}{l}\text { MDA-MB-231 } \\
\text { breast cancer cells }\end{array}$ & Invasion & [232] \\
\hline & $\begin{array}{l}\text { Arg753Gln and } \\
\text { (GT)n microsatellite } \\
\text { polymorphisms }\end{array}$ & $\begin{array}{l}\text { TLR2 overexpression } \\
\text { and increased NF- } \mathrm{B} \text {. } \\
\text { signaling }\end{array}$ & Colorectal cancer & $\begin{array}{l}\text { Growth, } \\
\text { progression, and } \\
\text { invasion }\end{array}$ & [233] \\
\hline & -196 to $-174 \mathrm{del}$ & $\begin{array}{l}\text { Decreased } \\
\text { transcription of } T L R 2 \\
\text { gene }\end{array}$ & $\begin{array}{l}\text { Breast cancer, } \\
\text { gastric cancer, } \\
\text { hepatocellular } \\
\text { carcinoma }\end{array}$ & $\begin{array}{l}\text { Tumor progression } \\
\text { due to weaker } \\
\text { immune response }\end{array}$ & [234-236] \\
\hline & Bacterial PGN & $\begin{array}{l}\text { Augmentation of } \\
\text { NF- } \mathrm{B} \text {, STAT3, and } \\
\text { Smad3 activities }\end{array}$ & Breast cancer & $\begin{array}{l}\text { Invasion and } \\
\text { adhesion }\end{array}$ & [237] \\
\hline
\end{tabular}


Table 1. Cont.

\begin{tabular}{|c|c|c|c|c|c|}
\hline TLRs & Agonist/Ligand & Mechanism & Cancer Type & $\begin{array}{l}\text { Enhanced Cancer } \\
\text { Characteristics }\end{array}$ & References \\
\hline \multirow{4}{*}{ TLR4 } & \multirow{4}{*}{ LPS } & $\begin{array}{l}\text { Increased secretion of } \\
\text { TGF- } \beta, \text { VEGF, and IL- } 8\end{array}$ & $\begin{array}{l}\text { Lung cancer, } \\
\text { ovarian cancer }\end{array}$ & $\begin{array}{l}\text { Immune evasion } \\
\text { and apoptosis } \\
\text { resistance }\end{array}$ & {$[238,239]$} \\
\hline & & $\begin{array}{l}\text { Activation of } \\
\text { PI3K-AKT signaling } \\
\text { and promotion of } \beta 1 \\
\text { integrin function }\end{array}$ & Colorectal cancer & $\begin{array}{l}\text { Increased } \\
\text { adhesiveness and } \\
\text { metastasis }\end{array}$ & [240] \\
\hline & & $\begin{array}{l}\text { Increased } \\
\text { mitochondrial ROS } \\
\text { production }\end{array}$ & $\begin{array}{l}\text { Gastric cancer, } \\
\text { non-small cell lung } \\
\text { cancer }\end{array}$ & $\begin{array}{l}\text { Increased cell } \\
\text { proliferation }\end{array}$ & {$[241,242]$} \\
\hline & & $\begin{array}{l}\text { Increased NF-кB } \\
\text { signaling }\end{array}$ & Pancreatic cancer & $\begin{array}{l}\text { Increased invasion } \\
\text { and progression }\end{array}$ & [243] \\
\hline TLR5 & Flagellin & $\begin{array}{l}\text { Enhanced activity of } \\
\text { NF- } \mathrm{B}, \mathrm{IL}-8 \text {, and ERK }\end{array}$ & Gastric cancer & Cell proliferation & [214] \\
\hline \multirow{3}{*}{ TLR7/8 } & ssRNA & $\begin{array}{l}\text { Activated NF- } k \mathrm{~B}, \\
\text { upregulation of Bcl-2 }\end{array}$ & Lung cancer & $\begin{array}{l}\text { Survival and } \\
\text { chemoresistance }\end{array}$ & [216] \\
\hline & Loxoribine & Enhanced signaling & NSCLC & $\begin{array}{l}\text { Progression and } \\
\text { chemoresistance }\end{array}$ & [245] \\
\hline & Resiquimod (R848) & $\begin{array}{l}\text { Elevated NF- } \mathrm{NB} \text { and } \\
\text { COX2 expression }\end{array}$ & Pancreatic cancer & $\begin{array}{l}\text { Proliferation and } \\
\text { chemoresistance }\end{array}$ & [246] \\
\hline
\end{tabular}

Abbreviations: BCL, B-cell lymphoma protein; CD, cluster of differentiation; COX, cyclooxygenase; CXCR, chemokine (C-X-C motif) receptor; ERK, extracellular signal-regulated kinase; hCAP, human cationic antimicrobial protein; ICAM, intercellular adhesion molecule; IFN, interferon; IL, interleukin; MMP, matrix metalloproteinase; NF- $\mathrm{B}$, nuclear factor $\kappa \mathrm{B}$; PI3K, phosphoinositide 3-kinase; RELA, REL-associated protein; ROS, reactive oxygen species; STAT, signal transducer and activator of transcription; TGF, transforming growth factor; TLR, Toll-like receptor; VEGF, vascular endothelial growth factor.

Table 2. TLRs with an antitumor effect.

\begin{tabular}{|c|c|c|c|c|c|}
\hline TLRs & Agonist/Ligand & Mechanism & Cancer Type & $\begin{array}{l}\text { Inhibited Cancer } \\
\text { Characteristics }\end{array}$ & References \\
\hline \multirow{2}{*}{ TLR2 } & MicroRNA-154 & $\begin{array}{l}\text { TLR2 downregulation } \\
\text { at post-transcription } \\
\text { level }\end{array}$ & Colorectal cancer & $\begin{array}{l}\text { Tumor growth, } \\
\text { migration, and } \\
\text { invasion }\end{array}$ & [251] \\
\hline & Krestin & $\begin{array}{l}\text { Stimulation of } \mathrm{CD}^{+} \mathrm{T} \\
\text { cells and NK cells }\end{array}$ & Breast cancer & Growth & {$[154]$} \\
\hline TLR3 & Poly(I:C) & $\begin{array}{l}\text { PI3K/AKT pathway } \\
\text { and autophagy }\end{array}$ & Prostate cancer & $\begin{array}{l}\text { Growth and } \\
\text { survival }\end{array}$ & [253] \\
\hline TLR4 & DAMPs & $\begin{array}{l}\text { Antitumor T cells } \\
\text { response with } \\
\text { activation of DCs }\end{array}$ & Colorectal cancer & Cell proliferation & [254] \\
\hline
\end{tabular}


Table 2. Cont

\begin{tabular}{|c|c|c|c|c|c|}
\hline TLRs & Agonist/Ligand & Mechanism & Cancer Type & $\begin{array}{l}\text { Inhibited Cancer } \\
\text { Characteristics }\end{array}$ & References \\
\hline \multirow{5}{*}{ TLR5 } & \multirow{5}{*}{ Flagellin } & $\begin{array}{l}\text { Increased IFN } \gamma: \mathrm{IL}-4 \\
\text { ratio and decreased } \\
\text { number of } \\
\mathrm{CD} 4^{+} \mathrm{CD} 25^{+} \mathrm{T}_{\text {reg }} \text { cells }\end{array}$ & $\begin{array}{l}\text { Tumor mouse } \\
\text { model }\end{array}$ & Tumor growth & [244] \\
\hline & & $\begin{array}{l}\mathrm{CD} 8^{+} \text {CTL immune } \\
\text { responses }\end{array}$ & Tumor model & $\begin{array}{l}\text { Growth and } \\
\text { survival }\end{array}$ & [256] \\
\hline & & $\begin{array}{l}\text { Increased MAP1S } \\
\text { expression }\end{array}$ & Breast cancer & $\begin{array}{l}\text { Tumor cell growth } \\
\text { and migration }\end{array}$ & [257] \\
\hline & & Increased signaling & NSCLC & $\begin{array}{l}\text { Cell proliferation, } \\
\text { migration, and } \\
\text { invasion }\end{array}$ & [258] \\
\hline & & Activated signaling & Breast cancer & $\begin{array}{l}\text { Cell growth and } \\
\text { proliferation }\end{array}$ & [224] \\
\hline \multirow{3}{*}{ TLR7/8 } & Imiquimod & $\begin{array}{l}\text { Establishment of } \\
\text { proimmunogenic } \\
\text { microenvironment }\end{array}$ & Breast cancer & Metastasis & [216] \\
\hline & Resiquimod (R848) & $\begin{array}{l}\text { Maturation and } \\
\text { differentiation of } \\
\text { MDSCs }\end{array}$ & Tumor model & Growth & [259] \\
\hline & Imiquimod & $\begin{array}{l}\text { Inhibition of nitric } \\
\text { oxide synthase }\end{array}$ & Tumor model & Growth & [260] \\
\hline \multirow{2}{*}{ TLR9 } & CpG ODN & Enhanced signaling & Neuroblastoma & $\begin{array}{l}\text { Growth and } \\
\text { survival }\end{array}$ & [261] \\
\hline & PF-3512676 & Enhanced signaling & Melanoma & Metastasis & {$[150,262]$} \\
\hline
\end{tabular}

Abbreviations: CTL, cytotoxic T lymphocyte; DCs, dendritic cells; dsRNA, double-stranded RNA; IFN, interferon; IL, interleukin; MAP1S, microtubule associated protein 1S; MDSCs, myeloid-derived suppressor cells; NK, natural killer; NSCLC: non-small cell lung cancer; ODN, oligodeoxynucleotide; PI3K, phosphoinositide 3-kinase; poly(I:C), polyinosinic:polycytidylic acid; $\mathrm{T}_{\text {reg }}$ cells, regulatory $\mathrm{T}$ cells.

\subsection{TLR Agonism for Cancer Prevention or Treatment}

\subsubsection{TLR2/TLR4}

Despite their protumor activity, TLR2 and TLR4 have been studied as components of adjuvants for vaccination and tumor therapy. For example, BCG switches on TLR2 and TLR4 thereby exerting antitumor immunomodulatory effects [263-267] especially in bladder cancer (FDA approval has already been obtained) [268-270]. Similarly, a derivative of Escherichia coli lipid A, OM-174 (CXR-526), engaging both TLR2 and TLR4, is being tested in a phase I trial against a solid tumor and phase I/II trials as a vaccine adjuvant for melanoma treatment. Stimuvax contains monophosphoryl lipid A, which stimulates TLR4; it is useful against the MUC1 tumor antigen but does not alleviate non-small cell lung carcinoma [271].

\subsubsection{TLR3}

The TLR3 ligand poly(I:C) has shown antitumor effects in several mouse studies [272,273], but hardly any data are available regarding humans. Several alternative ligands of TLR3 are being developed because of the rapid degradation of poly(I:C). For example, a poly(I:C) derivative (poly-ICLC; Hiltonol (R) is stabilized by poly-lysine and is being evaluated in a phase II clinical trial against a solid tumor. Another derivative, rintatolimod (Ampligen ${ }^{\circledR}$ ), features a substitution of cytidine with uridine at a 1:12 ratio and is used in the treatment of fallopian tube, ovarian, and brain tumors in combination with some vaccines. The administration of TLR3 ligand (poly(I:C)) reduces orthotopic prostate cancer in

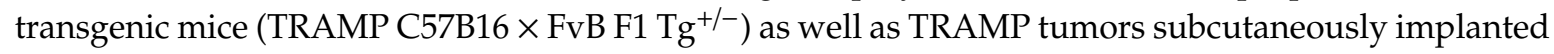
in syngenic mice [272]. Similarly, single administration of poly(I:C) into B16-F10-induced mouse model 
of metastatic lung cancer arrested tumor growth in association with greater influx of dendritic cells (DCs) which created cytotoxic immune environment [273].

\subsubsection{TLR5}

A TLR5 agonist, flagellin, and TLR5-agonistic nanoparticles have shown significant antitumor effects in mice [224,244,274]. Entolimod (CBLB502) derived from Salmonella flagellin [275] is a TLR5 agonist that is in phase I clinical trials against squamous cell head and neck cancer and solid tumors. The treatment of breast cancer cells with TLR5 agonist (flagellin) activated the intrinsic signaling pathway which led to the inhibition of anchorage-independent growth and cell-proliferation [224]. Another study showed the contrasting result of flagellin administration into mice subcutaneously transplanted with weak immunogenic tumor or its variant stably expressing strong antigenic HER-2 oncoprotein. Administration of flagellin after 8-10 days of tumor implantation significantly reduced the growth of antigenic variant tumor but not that of weakly immunogenic. In contrast, flagellin administration with antigenic-tumor implantation accelerated its growth. These contrasting results are because of increased ratio of IFN- $\gamma$ :IL- 4 and decreased number of $\mathrm{CD} 4{ }^{+} \mathrm{CD} 25^{+}$T regulatory cells in first case and vice versa. The early combinatorial treatment of flagellin with CpG-containing oligodeoxynucleotides completely suppressed the tumor growth [244].

\subsubsection{TLR7/8}

TLR7/8 are the most effective among all TLRs with respect to immunomodulatory anticancer effects. Hence, the only TLR agonist approved for cancer therapy is the one targeting TLR7/8, imiquimod. Both of these TLRs are activated simultaneously by the same ligand because of their common ability to recognize single-stranded RNA. The agonists of TLR7/8 have been classified into guanosine and adenosine analogs such as imiquimod and loxoribine, respectively. The ligands can be targeted specifically to TLR7 or TLR8 after modification of their RNA sequence [276]. Among all such ligands, imiquimod is in clinical use: the FDA and European Medicines Agency have approved Aldara (5\% imiquimod cream) for the treatment of basal cell carcinoma, and this substance has a $42-100 \%$ clearance rate $[277,278]$. It has also found applications in the treatment of other local cutaneous tumors, including lentigo maligna, with a $>85 \%$ success rate and significant clearance of melanoma [279]. Unlike imiquimod, 852A (a TLR7 agonist) and VTX-2337 (a TLR8 agonist) can be administered systemically and are being tested in phase I/II clinical trials against various malignant tumors, e.g., ovarian, breast, cervical, endometrial, and head and neck cancers.

\subsubsection{TLR9}

Various TLR9 agonists based on CpG oligodeoxynucleotides are being tested in animal models of neuroblastoma, cervical carcinoma, and colon cancer [261,280-283] and in some clinical trials [284]. Despite good preclinical results, several trials have been disappointing: there were safety issues of IMO-2055 with platinum-based therapies in a phase II trial against recurrent and metastatic head and neck cancer, and a phase III trial of CPG7909 failed against non-small cell lung cancer [228]. As a combinatorial therapy, CPG7909 (a TLR9 agonist), monophosphoryl lipid A (a TLR4 agonist), and MAGE-A3 (a melanoma antigen) are currently evaluated in phase III clinical studies.

\subsection{TLR Antagonism for Cancer Treatment or Prevention}

The protumor effects of TLRs in such organs as the liver, colon, and pancreas necessitate inhibition of TLR signaling at these sites for cancer treatment. Unfortunately, the results of studies on animal models cannot be translated into clinical trials so far. Promising antagonistic strategies are discussed below. 


\subsubsection{Manipulation of the Gut Microbiota}

The microbiota of intestines is rich in bacterial TLR ligands, which substantially participate in the carcinogenesis of the colon, stomach, and liver. TLR-mediated tumor-promoting and inflammatory signals can be reduced by modulating the bacterial translocation and/or gut microbiota by means of antibiotics or probiotics [285]. In murine models of azoxymethane (AOM)-induced colon cancer, the formation of aberrant cryptic foci is prevented by synbiotics but not by a pro- or prebiotic alone [286,287]. Administration of probiotic VSL\#3 in a rat model of liver carcinogenesis reduces the formation of a liver tumor [288]. In a genetic murine model of colorectal cancer, the expression of protumorigenic IL-23 in tumor-associated macrophages is reduced by short-term treatment with an antibiotic, whereas the number and size of tumors decrease with long-term suppression of the gut microbiota [289]. A reduction in the formation of colonic dysplasia is observed after sterilization of the gut in a colon cancer model [290]. The tumor burden in rat and mouse models is drastically reduced by sterilization of the gut with oral antibiotics [291,292]. The antibiotics are more effective if administered at later stages of hepatocarcinogenesis, indicating a possible role of the gut microbiota in cancer prevention, where early treatment is not possible. In murine hepatocarcinogenesis, a nonabsorbable well-tolerated antibiotic like rifaximin can decrease liver tumors [291] and is approved for the treatment of hepatic encephalopathy [293].

\subsubsection{Inhibition of TLR2 and TLR4}

Synthetic analogs derived from the lipid A portion of LPS (E5564 and CRX-526) inhibit TLR4 by preventing LPS binding to the TLR4-MD2 complex. The intracellular domain of TLR4 is targeted by another TLR4 inhibitor, TAK-242. Despite their inhibitory action on LPS-induced inflammation, they have not been tested for cancer prevention in either clinical trials or animal models [294-296]. Similarly, OPN305, a humanized monoclonal antibody, reduces in vivo inflammation but has not been tested regarding cancer prevention [297].

\section{Conclusions}

The prime purpose of TLRs is to help the human body to develop immunity by activating various downstream signaling pathways that result in the secretion of diverse proinflammatory cytokines. TLRs also perform a major function in tumor immunity by activating various cells such as DCs, T-cell subsets, and even tumor cells. This finding has led to the design of diverse TLR agonists as therapeutics against various cancers. Successful studies have involved a TLR7 agonist, imiquimod, and a nonspecific agonist of TLR2/TLR4, BCG. The discovery of new molecules, combinatorial therapies, and indications is in progress. An attractive possible tumor therapy is incorporation of TLR-specific agonists into cancer vaccination based on DCs [298]. Nonetheless, the activation of TLRs can also lead to inflammation that culminates in tumor promotion. Under this scenario, inhibition of TLR signaling may be useful for tumor regression. It is necessary to further study the "Yin-Yang" mechanisms of action of TLRs in tumor biology.

There is need to develop appropriate TLR-targeting drugs for the prevention/elimination of cancer. Several types of drug molecules exist based on their biochemical nature such as protein, small molecules, and aptamers. Each of them has its own benefits and drawbacks which affect physicochemical and pharmacokinetic properties of the associated drug. Discovering an appropriate drug is quite lengthy and complex process which involves target selection and its validation; compound screening and lead optimization; preclinical studies; and clinical trials. Target selection and library screening involve various computational approaches such as analysis of genome and proteome; high-throughput screening; virtual screening; and combinatorial chemistry. These traditional approaches are time-consuming and expensive. It would be better choice to use state-of-the-art and most advanced approaches like artificial intelligence (AI) for the screening of TLR-targeting 
compounds. More efficient and specific drug will lead to better and safe prevention of TLR-associated cancers with fewer side-effects.

Author Contributions: All authors have read and agree to the published version of the manuscript. Writing-Original Draft Preparation and Visualization, N.J.; Conceptualization and Writing-Review and Editing, S.C.

Funding: This research was funded by the National Research Foundation of Korea, grant numbers NRF-2019M3A9A8065098, 2019M3D1A1078940 and 2019R1A6A1A11051471.

Conflicts of Interest: The authors declare no conflict of interest.

\section{References}

1. Akira, S.; Uematsu, S.; Takeuchi, O. Pathogen recognition and innate immunity. Cell 2006, 124, 783-801. [CrossRef] [PubMed]

2. Iwasaki, A.; Medzhitov, R. Toll-like receptor control of the adaptive immune responses. Nat. Immunol. 2004, 5, 987. [CrossRef]

3. Bowie, A.; O'Neill, L.A. The interleukin-1 receptor/Toll-like receptor superfamily: signal generators for pro-inflammatory interleukins and microbial products. J. Leuko. Biol. 2000, 67, 508-514. [CrossRef] [PubMed]

4. Choe, J.; Kelker, M.S.; Wilson, I.A. Crystal structure of human toll-like receptor 3 (TLR3) ectodomain. Science 2005, 309, 581-585. [CrossRef] [PubMed]

5. Akira, S.; Takeda, K. Toll-like receptor signalling. Nat. Rev. Immunol. 2004, 4, 499. [CrossRef] [PubMed]

6. Javaid, N.; Yasmeen, F; Choi, S. Toll-Like Receptors and Relevant Emerging Therapeutics with Reference to Delivery Methods. Pharmaceutics 2019, 11, 441. [CrossRef]

7. Sato, S.; Sanjo, H.; Takeda, K.; Ninomiya-Tsuji, J.; Yamamoto, M.; Kawai, T.; Matsumoto, K.; Takeuchi, O.; Akira, S. Essential function for the kinase TAK1 in innate and adaptive immune responses. Nat. Immunol. 2005, 6, 1087. [CrossRef]

8. Campisi, J. Senescent cells, tumor suppression, and organismal aging: good citizens, bad neighbors. Cell 2005, 120, 513-522. [CrossRef]

9. Hanahan, D.; Weinberg, R.A. The hallmarks of cancer. Cell 2000, 100, 57-70. [CrossRef]

10. Bishop, J.M. Cancer: what should be done? American Association for the Advancement of Science, 1997.

11. Dunn, G.P.; Bruce, A.T.; Ikeda, H.; Old, L.J.; Schreiber, R.D. Cancer immunoediting: from immunosurveillance to tumor escape. Nat. Immunol. 2002, 3, 991. [CrossRef]

12. Pardoll, D. Does the immune system see tumors as foreign or self? Annu/Rev. Immunol. 2003, 21, 807-839. [CrossRef] [PubMed]

13. Boudreau, J.E.; Bonehill, A.; Thielemans, K.; Wan, Y. Engineering dendritic cells to enhance cancer immunotherapy. Mol. Ther. 2011, 19, 841-853. [CrossRef] [PubMed]

14. Fukata, M.; Abreu, M.T. Role of Toll-like receptors in gastrointestinal malignancies. Oncogene 2008, 27, 234. [CrossRef] [PubMed]

15. Spencer, E.; Jiang, J.; Chen, Z.J. Signal-induced ubiquitination of I $\mathrm{I} B \alpha$ by the F-box protein Slimb/ $\beta$-TrCP. Genes Dev. 1999, 13, 284-294. [CrossRef] [PubMed]

16. Chen, Z.J.; Parent, L.; Maniatis, T. Site-specific phosphorylation of $I \kappa B \alpha$ by a novel ubiquitination-dependent protein kinase activity. Cell 1996, 84, 853-862. [CrossRef]

17. Chen, Z.; Hagler, J.; Palombella, V.J;; Melandri, F.; Scherer, D.; Ballard, D.; Maniatis, T. Signal-induced site-specific phosphorylation targets I kappa B alpha to the ubiquitin-proteasome pathway. Genes Dev. 1995, 9, 1586-1597. [CrossRef] [PubMed]

18. Hayden, M.S.; Ghosh, S. Signaling to NF-kB. Genes Dev. 2004, 18, 2195-2224. [CrossRef]

19. Janssens, S.; Tinel, A.; Lippens, S.; Tschopp, J. PIDD mediates NF-KB activation in response to DNA damage. Cell 2005, 123, 1079-1092. [CrossRef]

20. Festjens, N.; Berghe, T.V.; Cornelis, S.; Vandenabeele, P. RIP1, a kinase on the crossroads of a cell's decision to live or die. Cell Death Differ. 2007, 14, 400. [CrossRef]

21. Wu, Z.-H.; Mabb, A.; Miyamoto, S. PIDD: a switch hitter. Cell 2005, 123, 980-982. [CrossRef]

22. Wu, C.-J.; Conze, D.B.; Li, T.; Srinivasula, S.M.; Ashwell, J.D. Sensing of Lys 63-linked polyubiquitination by NEMO is a key event in NF-kB activation. Nat. Cell Biol. 2006, 8, 398. [CrossRef] [PubMed] 
23. Zarnegar, B.J.; Wang, Y.; Mahoney, D.J.; Dempsey, P.W.; Cheung, H.H.; He, J.; Shiba, T.; Yang, X.; Yeh, W.-c.; Mak, T.W. Noncanonical NF- $\kappa B$ activation requires coordinated assembly of a regulatory complex of the adaptors cIAP1, cIAP2, TRAF2 and TRAF3 and the kinase NIK. Nat. Immunol. 2008, 9, 1371. [CrossRef] [PubMed]

24. Kato, T., Jr.; Delhase, M.; Hoffmann, A.; Karin, M. CK2 is a C-terminal IкB kinase responsible for NF- $\kappa$ B activation during the UV response. Mol. Cell 2003, 12, 829-839. [CrossRef]

25. Tergaonkar, V.; Bottero, V.; Ikawa, M.; Li, Q.; Verma, I.M. ІкB kinase-independent IкB $\alpha$ degradation pathway: functional NF-кB activity and implications for cancer therapy. Mol. Cell. Biol. 2003, 23, 8070-8083. [CrossRef] [PubMed]

26. Viatour, P.; Merville, M.-P.; Bours, V.; Chariot, A. Phosphorylation of NF-кB and IкB proteins: implications in cancer and inflammation. Trends Biochem. Sci. 2005, 30, 43-52. [CrossRef] [PubMed]

27. Aggarwal, B.B. Nuclear factor-kB: the enemy within. Cancer Cell 2004, 6, 203-208. [CrossRef] [PubMed]

28. Campbell, K.J.; Rocha, S.; Perkins, N.D. Active repression of antiapoptotic gene expression by RelA (p65) NF-кB. Mol. Cell 2004, 13, 853-865. [CrossRef]

29. Janssens, S.; Tschopp, J. Signals from within: the DNA-damage-induced NF-kB response. Cell Death Differ. 2006, 13, 773. [CrossRef]

30. Hur, G.M.; Lewis, J.; Yang, Q.; Lin, Y.; Nakano, H.; Nedospasov, S.; Liu, Z.-g. The death domain kinase RIP has an essential role in DNA damage-induced NF-kB activation. Genes Dev. 2003, 17, 873-882. [CrossRef]

31. Karin, M.; Greten, F.R. NF-кB: linking inflammation and immunity to cancer development and progression. Nat. Rev. Immunol. 2005, 5, 749. [CrossRef]

32. Singh, N.P.; Nagarkatti, M.; Nagarkatti, P.S. Role of dioxin response element and nuclear factor- $\kappa B$ motifs in 2, 3, 7, 8-tetrachlorodibenzo-p-dioxin-mediated regulation of Fas and Fas ligand expression. Mol. Pharmacol. 2007, 71, 145-157. [CrossRef] [PubMed]

33. Shou, Y.; Li, N.; Li, L.; Borowitz, J.L.; Isom, G.E. NF-кB-mediated up-regulation of Bcl-XS and Bax contributes to cytochrome c release in cyanide-induced apoptosis. J. Neurochem. 2002, 81, 842-852. [CrossRef] [PubMed]

34. Wang, P.; Qiu, W.; Dudgeon, C.; Liu, H.; Huang, C.; Zambetti, G.; Yu, J.; Zhang, L. PUMA is directly activated by NF- $\kappa$ B and contributes to TNF- $\alpha$-induced apoptosis. Cell Death Differ. 2009, 16, 1192. [CrossRef] [PubMed]

35. Sen, R.; Baltimore, D. Multiple nuclear factors interact with the immunoglobulin enhancer sequences. Cell 1986, 46, 705-716. [CrossRef]

36. Prasad, S.; Ravindran, J.; Aggarwal, B.B. NF-кB and cancer: how intimate is this relationship. Mol. Cell. Biochem. 2010, 336, 25-37. [CrossRef] [PubMed]

37. Nelson, D.; Ihekwaba, A.; Elliott, M.; Johnson, J.; Gibney, C.; Foreman, B.; Nelson, G.; See, V.; Horton, C.; Spiller, D. Oscillations in NF- $\kappa B$ signaling control the dynamics of gene expression. Science 2004, 306, 704-708. [CrossRef]

38. Baldwin, A.S. Regulation of cell death and autophagy by IKK and NF- $\mathrm{kB}$ : critical mechanisms in immune function and cancer. Immunol. Rev. 2012, 246, 327-345. [CrossRef]

39. Chu, Z.-L.; McKinsey, T.A.; Liu, L.; Gentry, J.J.; Malim, M.H.; Ballard, D.W. Suppression of tumor necrosis factor-induced cell death by inhibitor of apoptosis c-IAP2 is under NF-kB control. Proc. Natl. Acad. Sci. USA 1997, 94, 10057-10062. [CrossRef]

40. Wang, C.-Y.; Mayo, M.W.; Korneluk, R.G.; Goeddel, D.V.; Baldwin, A.S. NF-кB antiapoptosis: induction of TRAF1 and TRAF2 and c-IAP1 and c-IAP2 to suppress caspase-8 activation. Science 1998, 281, 1680-1683. [CrossRef]

41. Basseres, D.; Baldwin, A. Nuclear factor- $\kappa \mathrm{B}$ and inhibitor of $\kappa \mathrm{B}$ kinase pathways in oncogenic initiation and progression. Oncogene 2006, 25, 6817. [CrossRef]

42. Hinz, M.; Krappmann, D.; Eichten, A.; Heder, A.; Scheidereit, C.; Strauss, M. NF-кB function in growth control: regulation of cyclin D1 expression and G0/G1-to-S-phase transition. Mol. Cell. Biol. 1999, 19, 2690-2698. [CrossRef] [PubMed]

43. Cao, Y.; Bonizzi, G.; Seagroves, T.N.; Greten, F.R.; Johnson, R.; Schmidt, E.V.; Karin, M. IKK $\alpha$ provides an essential link between RANK signaling and cyclin D1 expression during mammary gland development. Cell 2001, 107, 763-775. [CrossRef]

44. Chang, L.; Karin, M. Mammalian MAP kinase signalling cascades. Nature 2001, 410, 37. [CrossRef] [PubMed]

45. Krens, S.G.; Spaink, H.P.; Snaar-Jagalska, B.E. Functions of the MAPK family in vertebrate-development. FEBS Lett. 2006, 580, 4984-4990. [CrossRef] [PubMed] 
46. Kyriakis, J.M.; Avruch, J. Mammalian mitogen-activated protein kinase signal transduction pathways activated by stress and inflammation. Physiol. Rev. 2001, 81, 807-869. [CrossRef]

47. McKay, M.; Morrison, D. Integrating signals from RTKs to ERK/MAPK. Oncogene 2007, 26, 3113. [CrossRef]

48. Raman, M.; Chen, W.; Cobb, M. Differential regulation and properties of MAPKs. Oncogene 2007, 26, 3100. [CrossRef]

49. Yoon, S.; Seger, R. The extracellular signal-regulated kinase: multiple substrates regulate diverse cellular functions. Growth Factors 2006, 24, 21-44. [CrossRef]

50. Dunn, K.L.; Espino, P.S.; Drobic, B.; He, S.; Davie, J.R. The Ras-MAPK signal transduction pathway, cancer and chromatin remodeling. Biochem. Cell Biol. 2005, 83, 1-14. [CrossRef]

51. Murphy, L.O.; MacKeigan, J.P.; Blenis, J. A network of immediate early gene products propagates subtle differences in mitogen-activated protein kinase signal amplitude and duration. Mol. Cell. Biol. 2004, 24, 144-153. [CrossRef]

52. Yamamoto, T.; Ebisuya, M.; Ashida, F.; Okamoto, K.; Yonehara, S.; Nishida, E. Continuous ERK activation downregulates antiproliferative genes throughout G1 phase to allow cell-cycle progression. Curr. Biol. 2006, 16, 1171-1182. [CrossRef] [PubMed]

53. Mirza, A.M.; Gysin, S.; Malek, N.; Nakayama, K.-i.; Roberts, J.M.; McMahon, M. Cooperative regulation of the cell division cycle by the protein kinases RAF and AKT. Mol. and cellular Biol. 2004, 24, 10868-10881. [CrossRef] [PubMed]

54. Coleman, M.L.; Marshall, C.J.; Olson, M.F. RAS and RHO GTPases in G1-phase cell-cycle regulation. Nat. Rev. Mol. Cell Biol. 2004, 5, 355. [CrossRef] [PubMed]

55. Miyoshi, K.; Wakioka, T.; Nishinakamura, H.; Kamio, M.; Yang, L.; Inoue, M.; Hasegawa, M.; Yonemitsu, Y.; Komiya, S.; Yoshimura, A. The Sprouty-related protein, Spred, inhibits cell motility, metastasis, and Rho-mediated actin reorganization. Oncogene 2004, 23, 5567. [CrossRef] [PubMed]

56. Bloethner, S.; Chen, B.; Hemminki, K.; Müller-Berghaus, J.; Ugurel, S.; Schadendorf, D.; Kumar, R. Effect of common B-RAF and N-RAS mutations on global gene expression in melanoma cell lines. Carcinogenesis 2005, 26, 1224-1232. [CrossRef]

57. Saitoh, M.; Nishitoh, H.; Fujii, M.; Takeda, K.; Tobiume, K.; Sawada, Y.; Kawabata, M.; Miyazono, K.; Ichijo, H. Mammalian thioredoxin is a direct inhibitor of apoptosis signal-regulating kinase (ASK) 1. EMBO J. 1998, 17, 2596-2606. [CrossRef]

58. Dérijard, B.; Hibi, M.; Wu, I.-H.; Barrett, T.; Su, B.; Deng, T.; Karin, M.; Davis, R.J. JNK1: a protein kinase stimulated by UV light and Ha-Ras that binds and phosphorylates the c-Jun activation domain. Cell 1994, 76, 1025-1037. [CrossRef]

59. Kyriakis, J.M.; Banerjee, P.; Nikolakaki, E.; Dai, T.; Rubie, E.A.; Ahmad, M.F.; Avruch, J.; Woodgett, J.R. The stress-activated protein kinase subfamily of c-Jun kinases. Nature 1994, 369, 156. [CrossRef]

60. Weston, C.R.; Davis, R.J. The JNK signal transduction pathway. Curr. Opin. Cell Biol. 2007, 19, $142-149$. [CrossRef]

61. Kyriakis, J.; Brautigan, D.; Ingebritsen, T.; Avruch, J. pp54 microtubule-associated protein-2 kinase requires both tyrosine and serine/threonine phosphorylation for activity. J. Biol. Chem. 1991, 266, 10043-10046.

62. Dai, T.; Rubie, E.; Franklin, C.; Kraft, A.; Gillespie, D.; Avruch, J.; Kyriakis, J.; Woodgett, J. Stress-activated protein kinases bind directly to the delta domain of c-Jun in resting cells: implications for repression of c-Jun function. Oncogene 1995, 10, 849-855. [PubMed]

63. Kallunki, T.; Su, B.; Tsigelny, I.; Sluss, H.K.; Dérijard, B.; Moore, G.; Davis, R.; Karin, M. JNK2 contains a specificity-determining region responsible for efficient c-Jun binding and phosphorylation. Genes Dev. 1994, 8, 2996-3007. [CrossRef] [PubMed]

64. Kennedy, N.J.; Davis, R.J. Role of JNK in tumor development. Cell Cycle 2003, 2, 199-201. [PubMed]

65. Johnson, R.; Spiegelman, B.; Hanahan, D.; Wisdom, R. Cellular transformation and malignancy induced by ras require c-jun. Mol. Cell. Biol. 1996, 16, 4504-4511. [CrossRef]

66. Eferl, R.; Ricci, R.; Kenner, L.; Zenz, R.; David, J.-P.; Rath, M.; Wagner, E.F. Liver tumor development: c-Jun antagonizes the proapoptotic activity of p53. Cell 2003, 112, 181-192. [CrossRef]

67. Kennedy, N.J.; Sluss, H.K.; Jones, S.N.; Bar-Sagi, D.; Flavell, R.A.; Davis, R.J. Suppression of Ras-stimulated transformation by the JNK signal transduction pathway. Genes $\mathcal{E}$ development 2003, 17, 629-637.

68. Vasilevskaya, I.; O'Dwyer, P.J. Role of Jun and Jun kinase in resistance of cancer cells to therapy. Drug Resist. Updat. 2003, 6, 147-156. [CrossRef] 
69. Bubici, C.; Papa, S.; Pham, C.G.; Zazzeroni, F.; Franzoso, G. NF-кB and JNK: an intricate affair. Cell Cycle 2004, 3, 1524-1529. [CrossRef]

70. Javelaud, D.; Besançon, F. NF- $\mathrm{KB}$ activation results in rapid inactivation of JNK in TNF $\alpha$-treated Ewing sarcoma cells: a mechanism for the anti-apoptotic effect of NF-кB. Oncogene 2001, 20, 4365. [CrossRef]

71. Han, J.; Lee, J.; Bibbs, L.; Ulevitch, R. A MAP kinase targeted by endotoxin and hyperosmolarity in mammalian cells. Science 1994, 265, 808-811. [CrossRef]

72. Herskowitz, I. MAP kinase pathways in yeast: for mating and more. Cell 1995, 80, 187-197. [CrossRef]

73. Freshney, N.W.; Rawlinson, L.; Guesdon, F.; Jones, E.; Cowley, S.; Hsuan, J.; Saklatvala, J. Interleukin-1 activates a novel protein kinase cascade that results in the phosphorylation of Hsp27. Cell 1994, 78, 1039-1049. [CrossRef]

74. Rouse, J.; Cohen, P.; Trigon, S.; Morange, M.; Alonso-Llamazares, A.; Zamanillo, D.; Hunt, T.; Nebreda, A.R. A novel kinase cascade triggered by stress and heat shock that stimulates MAPKAP kinase-2 and phosphorylation of the small heat shock proteins. Cell 1994, 78, 1027-1037. [CrossRef]

75. Goedert, M.; Cuenda, A.; Craxton, M.; Jakes, R.; Cohen, P. Activation of the novel stress-activated protein kinase SAPK4 by cytokines and cellular stresses is mediated by SKK3 (MKK6); comparison of its substrate specificity with that of other SAP kinases. EMBO J. 1997, 16, 3563-3571. [CrossRef] [PubMed]

76. Jiang, Y.; Chen, C.; Li, Z.; Guo, W.; Gegner, J.A.; Lin, S.; Han, J. Characterization of the structure and function of a new mitogen-activated protein kinase (p38ß). J. Biol. Chem. 1996, 271, 17920-17926. [CrossRef]

77. Jiang, Y.; Gram, H.; Zhao, M.; New, L.; Gu, J.; Feng, L.; Di Padova, F.; Ulevitch, R.J.; Han, J. Characterization

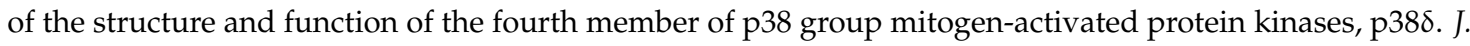
Biol. Chem. 1997, 272, 30122-30128. [CrossRef]

78. Lee, J.C.; Laydon, J.T.; McDonnell, P.C.; Gallagher, T.F.; Kumar, S.; Green, D.; McNulty, D.; Blumenthal, M.J.; Keys, J.R.; Strickler, J.E. A protein kinase involved in the regulation of inflammatory cytokine biosynthesis. Nature 1994, 372, 739. [CrossRef]

79. Eyers, P.A.; Craxton, M.; Morricel, N.; Cohen, P.; Goedert, M. Conversion of SB 203580-insensitive MAP kinase family members to drug-sensitive forms by a single amino-acid substitution. Chem. Biol. 1998, 5, 321-328. [CrossRef]

80. Saklatvala, J. The p38 MAP kinase pathway as a therapeutic target in inflammatory disease. Curr. Opin. Pharmacol. 2004, 4, 372-377. [CrossRef]

81. Hirai, S.-I.; Noda, K.; Moriguchi, T.; Nishida, E.; Yamashita, A.; Deyama, T.; Fukuyama, K.; Ohno, S. Differential activation of two JNK activators, MKK7 and SEK1, by MKN28-derived nonreceptor serine/threonine kinase/mixed lineage kinase 2. J. Biol. Chem. 1998, 273, 7406-7412. [CrossRef]

82. Zarubin, T.; Jiahuai, H. Activation and signaling of the p38 MAP kinase pathway. Cell Res. 2005, 15, 11. [CrossRef] [PubMed]

83. Bulavin, D.V.; Fornace, A.J. p38 MAP kinase's emerging role as a tumor suppressor. Advances Cancer Res. 2004, 92, 95-118.

84. Timofeev, O.; Lee, T.Y.; Bulavin, D.V. A subtle change in p38 MAPK activity is sufficient to suppress in vivo tumorigenesis. Cell Cycle 2005, 4, 118-120. [CrossRef] [PubMed]

85. Pruitt, K.; Pruitt, W.M.; Bilter, G.K.; Westwick, J.K.; Der, C.J. Raf-independent deregulation of p38 and JNK mitogen-activated protein kinases are critical for Ras transformation. J. Biol. Chem. 2002, 277, 31808-31817. [CrossRef]

86. She, Q.-B.; Bode, A.M.; Ma, W.-Y.; Chen, N.-Y.; Dong, Z. Resveratrol-induced activation of p53 and apoptosis is mediated by extracellular-signal-regulated protein kinases and p38 kinase. Cancer Res. 2001, 61, 1604-1610.

87. Bulavin, D.V.; Kovalsky, O.; Hollander, M.C.; Fornace Jr, A.J. Loss of oncogenic H-ras-induced cell cycle arrest and p38 mitogen-activated protein kinase activation by disruption of Gadd45a. Mol. and cellular Biol. 2003, 23, 3859-3871. [CrossRef]

88. Iyoda, K.; Sasaki, Y.; Horimoto, M.; Toyama, T.; Yakushijin, T.; Sakakibara, M.; Takehara, T.; Fujimoto, J.; Hori, M.; Wands, J.R. Involvement of the p38 mitogen-activated protein kinase cascade in hepatocellular carcinoma. Cancer 2003, 97, 3017-3026. [CrossRef]

89. Olson, J.M.; Hallahan, A.R. p38 MAP kinase: a convergence point in cancer therapy. Trends Mol. Med. 2004, 10, 125-129. [CrossRef] 
90. Deacon, K.; Mistry, P.; Chernoff, J.; Blank, J.L.; Patel, R. p38 Mitogen-activated protein kinase mediates cell death and p21-activated kinase mediates cell survival during chemotherapeutic drug-induced mitotic arrest. Mol. Biol. Cell 2003, 14, 2071-2087. [CrossRef]

91. Losa, J.H.; Cobo, C.P.; Viniegra, J.G.; Lobo, V.J.S.-A.; y Cajal, S.R.; Sanchez-Prieto, R. Role of the p38 MAPK pathway in cisplatin-based therapy. Oncogene 2003, 22, 3998. [CrossRef]

92. Lee, E.-R.; Kim, J.-Y.; Kang, Y.-J.; Ahn, J.-Y.; Kim, J.-H.; Kim, B.-W.; Choi, H.-Y.; Jeong, M.-Y.; Cho, S.-G. Interplay between PI3K/Akt and MAPK signaling pathways in DNA-damaging drug-induced apoptosis. Biochimica et Biophysica Acta (BBA)-Mol. Cell Res. 2006, 1763, 958-968. [CrossRef] [PubMed]

93. Hardy, M.P.; Owczarek, C.M.; Jermiin, L.S.; Ejdebäck, M.; Hertzog, P.J. Characterization of the type I interferon locus and identification of novel genes. Genomics 2004, 84, 331-345. [CrossRef] [PubMed]

94. Van Pesch, V.; Lanaya, H.; Renauld, J.-C.; Michiels, T. Characterization of the murine alpha interferon gene family. J. Virol. 2004, 78, 8219-8228. [CrossRef] [PubMed]

95. Pestka, S. The human interferon $\alpha$ species and receptors. Peptide Sci. 2000, 55, 254-287. [CrossRef]

96. Zhou, A.; Hassel, B.A.; Silverman, R.H. Expression cloning of 2-5A-dependent RNAase: a uniquely regulated mediator of interferon action. Cell 1993, 72, 753-765. [CrossRef]

97. Lu, J.; O'Hara, E.B.; Trieselmann, B.A.; Romano, P.R.; Dever, T.E. The interferon-induced double-stranded RNA-activated protein kinase PKR will phosphorylate serine, threonine, or tyrosine at residue 51 in eukaryotic initiation factor $2 \alpha$. J. Biol. Chem. 1999, 274, 32198-32203. [CrossRef]

98. Stranden, A.M.; Staeheli, P.; Pavlovic, J. Function of the mouse Mx1 protein is inhibited by overexpression of the PB2 protein of influenza virus. Virology 1993, 197, 642-651. [CrossRef]

99. Hu, X.; Bies, J.; Wolff, L. Interferon beta increases c-Myc proteolysis in mouse monocyte/macrophage leukemia cells. Leukemia Res. 2005, 29, 1307-1314. [CrossRef]

100. Iacopino, F.; Ferrandina, G.; Scambia, G.; Benedetti-Panici, P.; Mancuso, S.; Sica, G. Interferons inhibit EGF-stimulated cell growth and reduce EGF binding in human breast cancer cells. Anticancer Res. 1996, 16, 1919-1924.

101. Hamilton, J.A.; Whitty, G.A.; Kola, I.; Hertzog, P.J. Endogenous IFN-alpha beta suppresses colony-stimulating factor (CSF)-1-stimulated macrophage DNA synthesis and mediates inhibitory effects of lipopolysaccharide and TNF-alpha. J. Immunol. 1996, 156, 2553-2557.

102. Hwang, S.Y.; Hertzog, P.J.; Holland, K.A.; Sumarsono, S.H.; Tymms, M.J.; Hamilton, J.A.; Whitty, G.; Bertoncello, I.; Kola, I. A null mutation in the gene encoding a type I interferon receptor component eliminates antiproliferative and antiviral responses to interferons alpha and beta and alters macrophage responses. Proc. Natl. Acad. Sci. USA 1995, 92, 11284-11288. [CrossRef] [PubMed]

103. Sun, S.; Zhang, X.; Tough, D.; Sprent, J. Multiple effects of immunostimulatory DNA on T cells and the role of type I interferons. Immunostimulatory DNA Seq. 2001, 22, 77-84.

104. Chawla-Sarkar, M.; Lindner, D.J.; Liu, Y.-F.; Williams, B.; Sen, G.C.; Silverman, R.H.; Borden, E.C. Apoptosis and interferons: role of interferon-stimulated genes as mediators of apoptosis. Apoptosis 2003, 8, 237-249. [CrossRef] [PubMed]

105. Juang, S.-H.; Wei, S.-J.; Hung, Y.-M.; Hsu, C.-Y.; Yang, D.-M.; Liu, K.-J.; Chen, W.-S.; Yang, W.K. IFN- $\beta$ induces caspase-mediated apoptosis by disrupting mitochondria in human advanced stage colon cancer cell lines. J. Interferon Cytokine Res. 2004, 24, 231-243. [CrossRef] [PubMed]

106. Kirou, K.A.; Krishna, R.; Maria, V.; Butler, J.; Crow, M.K. Induction of Fas ligand-mediated apoptosis by interferon- $\alpha$. Clin. Immunol. 2000, 95, 218-226. [CrossRef] [PubMed]

107. Oshima, K.; Yanase, N.; Ibukiyama, C.; Yamashina, A.; Kayagaki, N.; Yagita, H.; Mizuguchi, J. Involvement of TRAIL/TRAIL-R interaction in IFN- $\alpha$-induced apoptosis of Daudi B lymphoma cells. Cytokine 2001, 14, 193-201. [CrossRef]

108. Sanceau, J.; Hiscott, J.; Delattre, O.; Wietzerbin, J. IFN- $\beta$ induces serine phosphorylation of Stat-1 in Ewing's sarcoma cells and mediates apoptosis via induction of IRF-1 and activation of caspase-7. Oncogene 2000, 19, 3372. [CrossRef]

109. Zhou, A.; Paranjape, J.; Brown, T.L.; Nie, H.; Naik, S.; Dong, B.; Chang, A.; Trapp, B.; Fairchild, R.; Colmenares, C. Interferon action and apoptosis are defective in mice devoid of $2^{\prime}, 5^{\prime}$-oligoadenylate-dependent RNase L. EMBO J. 1997, 16, 6355-6363. [CrossRef]

110. Rogge, L.; D'Ambrosio, D.; Biffi, M.; Penna, G.; Minetti, L.J.; Presky, D.H.; Adorini, L.; Sinigaglia, F. The role of Stat4 in species-specific regulation of Th cell development by type I IFNs. J. Immunol. 1998, 161, 6567-6574. 
111. Blanco, P.; Palucka, A.K.; Gill, M.; Pascual, V.; Banchereau, J. Induction of dendritic cell differentiation by IFN- $\alpha$ in systemic lupus erythematosus. Science 2001, 294, 1540-1543. [CrossRef]

112. Theofilopoulos, A.N.; Baccala, R.; Beutler, B.; Kono, D.H. Type I interferons $(\alpha / \beta)$ in immunity and autoimmunity. Annu. Rev. Immunol. 2005, 23, 307-335. [CrossRef] [PubMed]

113. Biron, C.A.; Nguyen, K.B.; Pien, G.C.; Cousens, L.P.; Salazar-Mather, T.P. Natural killer cells in antiviral defense: function and regulation by innate cytokines. Annu. Rev. Immunol. 1999, 17, 189-220. [CrossRef] [PubMed]

114. Salazar-Mather, T.P.; Lewis, C.A.; Biron, C.A. Type I interferons regulate inflammatory cell trafficking and macrophage inflammatory protein $1 \alpha$ delivery to the liver. J. Clin. Invest. 2002, 110, 321-330. [CrossRef]

115. Thomas, K.E.; Galligan, C.L.; Newman, R.D.; Fish, E.N.; Vogel, S.N. Contribution of interferon- $\beta$ to the murine macrophage response to the Toll-like receptor 4 agonist, lipopolysaccharide. J. Biol. Chem. 2006, 281, 31119-31130. [CrossRef]

116. Hennessy, E.J.; Parker, A.E.; O'neill, L.A. Targeting Toll-like receptors: emerging therapeutics? Nat. Rev. Drug Discov. 2010, 9, 293. [CrossRef]

117. So, E.Y.; Ouchi, T. The application of Toll like receptors for cancer therapy. Int. J. Biol. Sci. 2010, 6, 675. [CrossRef]

118. Rudilla, F.; Fayolle, C.; Casares, N.; Durantez, M.; Arribillaga, L.; Lozano, T.; Villanueva, L.; Pio, R.; Sarobe, P.; Leclerc, C. Combination of a TLR4 ligand and anaphylatoxin C5a for the induction of antigen-specific cytotoxic T cell responses. Vaccine 2012, 30, 2848-2858. [CrossRef]

119. Stone, G.W.; Barzee, S.; Snarsky, V.; Santucci, C.; Tran, B.; Langer, R.; Zugates, G.T.; Anderson, D.G.; Kornbluth, R.S. Nanoparticle-delivered multimeric soluble CD40L DNA combined with Toll-Like Receptor agonists as a treatment for melanoma. PLoS One 2009, 4, e7334. [CrossRef]

120. Schneider, C.; Schmidt, T.; Ziske, C.; Tiemann, K.; Lee, K.; Uhlinsky, V.; Behrens, P.; Sauerbruch, T.; Schmidt-Wolf, I.; Mühlradt, P. Tumour suppression induced by the macrophage activating lipopeptide MALP-2 in an ultrasound guided pancreatic carcinoma mouse model. Gut 2004, 53, 355-361. [CrossRef]

121. Triozzi, P.L.; Aldrich, W.; Ponnazhagan, S. Inhibition and promotion of tumor growth with adeno-associated virus carcinoembryonic antigen vaccine and Toll-like receptor agonists. Cancer Gene Ther. 2011, 18, 850. [CrossRef]

122. Broomfield, S.A.; Van Der Most, R.G.; Prosser, A.C.; Mahendran, S.; Tovey, M.G.; Smyth, M.J.; Robinson, B.W.; Currie, A.J. Locally administered TLR7 agonists drive systemic antitumor immune responses that are enhanced by anti-CD40 immunotherapy. J. Immunol. 2009, 182, 5217-5224. [CrossRef] [PubMed]

123. Davis, M.B.; Vasquez-Dunddel, D.; Fu, J.; Albesiano, E.; Pardoll, D.; Kim, Y.J. Intratumoral administration of TLR4 agonist absorbed into a cellular vector improves antitumor responses. Clin. Cancer Res. 2011, 17, 3984-3992. [CrossRef] [PubMed]

124. Sobek, V.; Birkner, N.; Falk, I.; Würch, A.; Kirschning, C.J.; Wagner, H.; Wallich, R.; Lamers, M.C.; Simon, M.M. Direct Toll-like receptor 2 mediated co-stimulation of $\mathrm{T}$ cells in the mouse system as a basis for chronic inflammatory joint disease. Arthritis Res. Ther. 2004, 6, R433. [CrossRef] [PubMed]

125. Asprodites, N.; Zheng, L.; Geng, D.; Velasco-Gonzalez, C.; Sanchez-Perez, L.; Davila, E. Engagement of Toll-like receptor-2 on cytotoxic T-lymphocytes occurs in vivo and augments antitumor activity. FASEB J. 2008, 22, 3628-3637. [CrossRef] [PubMed]

126. Cottalorda, A.; Verschelde, C.; Marçais, A.; Tomkowiak, M.; Musette, P.; Uematsu, S.; Akira, S.; Marvel, J.; Bonnefoy-Berard, N. TLR2 engagement on CD8 T cells lowers the thresholdfor optimal antigen-induced T cell activation. Eur. J. Immunol. 2006, 36, 1684-1693. [CrossRef] [PubMed]

127. Morrison, C.; Baer, M.R.; Zandberg, D.P.; Kimball, A.; Davila, E. Effects of Toll-like receptor signals in T-cell neoplasms. Future Oncol. 2011, 7, 309-320. [CrossRef]

128. Babu, S.; Blauvelt, C.P.; Kumaraswami, V.; Nutman, T.B. Cutting edge: diminished T cell TLR expression and function modulates the immune response in human filarial infection. J. Immunol. 2006, 176, 3885-3889. [CrossRef]

129. Hervas-Stubbs, S.; Olivier, A.; Boisgerault, F.; Thieblemont, N.; Leclerc, C. TLR3 ligand stimulates fully functional memory CD8+ T cells in the absence of CD4+ T-cell help. Blood 2007, 109, 5318-5326. [CrossRef]

130. Banchereau, J.; Steinman, R.M. Dendritic cells and the control of immunity. Nature 1998, 392, 245. [CrossRef]

131. Shortman, K.; Liu, Y.-J. Mouse and human dendritic cell subtypes. Nat. Rev. Immunol. 2002, 2, 151. [CrossRef] 
132. Piccioli, D.; Tavarini, S.; Borgogni, E.; Steri, V.; Nuti, S.; Sammicheli, C.; Bardelli, M.; Montagna, D.; Locatelli, F.; Wack, A. Functional specialization of human circulating CD16 and CD1c myeloid dendritic-cell subsets. Blood 2007, 109, 5371-5379. [CrossRef] [PubMed]

133. Hovanessian, A.G. On the discovery of interferon-inducible, double-stranded RNA activated enzymes: the $2^{\prime}-5^{\prime}$ oligoadenylate synthetases and the protein kinase PKR. Cytokine Growth Factor Rev. 2007, 18, 351-361. [CrossRef] [PubMed]

134. Jarrossay, D.; Napolitani, G.; Colonna, M.; Sallusto, F.; Lanzavecchia, A. Specialization and complementarity in microbial molecule recognition by human myeloid and plasmacytoid dendritic cells. Eur. J. Immunol. 2001, 31, 3388-3393. [CrossRef]

135. Kadowaki, N.; Ho, S.; Antonenko, S.; de Waal Malefyt, R.; Kastelein, R.A.; Bazan, F.; Liu, Y.-J. Subsets of human dendritic cell precursors express different toll-like receptors and respond to different microbial antigens. J. Exp. Med. 2001, 194, 863-870. [CrossRef] [PubMed]

136. Ito, T.; Amakawa, R.; Kaisho, T.; Hemmi, H.; Tajima, K.; Uehira, K.; Ozaki, Y.; Tomizawa, H.; Akira, S.; Fukuhara, S. Interferon- $\alpha$ and interleukin-12 are induced differentially by Toll-like receptor 7 ligands in human blood dendritic cell subsets. J. Exp. Med. 2002, 195, 1507-1512. [CrossRef] [PubMed]

137. Krug, A.; Towarowski, A.; Britsch, S.; Rothenfusser, S.; Hornung, V.; Bals, R.; Giese, T.; Engelmann, H.; Endres, S.; Krieg, A.M. Toll-like receptor expression reveals CpG DNA as a unique microbial stimulus for plasmacytoid dendritic cells which synergizes with CD40 ligand to induce high amounts of IL-12. Eur. J. Immunol. 2001, 31, 3026-3037. [CrossRef]

138. Hasan, U.; Chaffois, C.; Gaillard, C.; Saulnier, V.; Merck, E.; Tancredi, S.; Guiet, C.; Brière, F.; Vlach, J.; Lebecque, S. Human TLR10 is a functional receptor, expressed by B cells and plasmacytoid dendritic cells, which activates gene transcription through MyD88. J. Immunol. 2005, 174, 2942-2950. [CrossRef]

139. Boonstra, A.; Asselin-Paturel, C.; Gilliet, M.; Crain, C.; Trinchieri, G.; Liu, Y.-J.; O'Garra, A. Flexibility of mouse classical and plasmacytoid-derived dendritic cells in directing $\mathrm{T}$ helper type 1 and 2 cell development: dependency on antigen dose and differential toll-like receptor ligation. J. Exp. Med. 2003, 197, 101-109. [CrossRef]

140. Salio, M.; Cella, M.; Vermi, W.; Facchetti, F.; Palmowski, M.J.; Smith, C.L.; Shepherd, D.; Colonna, M.; Cerundolo, V. Plasmacytoid dendritic cells prime IFN- $\gamma$-secreting melanoma-specific CD8 lymphocytes and are found in primary melanoma lesions. Eur. J. Immunol. 2003, 33, 1052-1062. [CrossRef]

141. Zou, W.; Machelon, V.; Coulomb-L’Hermin, A.; Borvak, J.; Nome, F.; Isaeva, T.; Wei, S.; Krzysiek, R.; Durand-Gasselin, I.; Gordon, A. Stromal-derived factor-1 in human tumors recruits and alters the function of plasmacytoid precursor dendritic cells. Nat. Med. 2001, 7, 1339. [CrossRef]

142. Hartmann, E.; Wollenberg, B.; Rothenfusser, S.; Wagner, M.; Wellisch, D.; Mack, B.; Giese, T.; Gires, O.; Endres, S.; Hartmann, G. Identification and functional analysis of tumor-infiltrating plasmacytoid dendritic cells in head and neck cancer. Cancer Res. 2003, 63, 6478-6487. [PubMed]

143. Treilleux, I.; Blay, J.-Y.; Bendriss-Vermare, N.; Ray-Coquard, I.; Bachelot, T.; Guastalla, J.-P.; Bremond, A.; Goddard, S.; Pin, J.-J.; Barthelemy-Dubois, C. Dendritic cell infiltration and prognosis of early stage breast cancer. Clin. Cancer Res. 2004, 10, 7466-7474. [CrossRef] [PubMed]

144. Gabrilovich, D.I.; Corak, J.; Ciernik, I.F.; Kavanaugh, D.; Carbone, D.P. Decreased antigen presentation by dendritic cells in patients with breast cancer. Clin. Cancer Res. 1997, 3, 483-490. [PubMed]

145. Bell, D.; Chomarat, P.; Broyles, D.; Netto, G.; Harb, G.M.; Lebecque, S.; Valladeau, J.; Davoust, J.; Palucka, K.A.; Banchereau, J. In breast carcinoma tissue, immature dendritic cells reside within the tumor, whereas mature dendritic cells are located in peritumoral areas. J. Exp. Med. 1999, 190, 1417-1426. [CrossRef]

146. Menetrier-Caux, C.; Montmain, G.; Dieu, M.; Bain, C.; Favrot, M.; Caux, C.; Blay, J. Inhibition of the differentiation of dendritic cells from CD34+ progenitors by tumor cells: role of interleukin- 6 and macrophage colony-stimulating factor. Blood 1998, 92, 4778-4791. [CrossRef]

147. Wei, S.; Kryczek, I.; Zou, L.; Daniel, B.; Cheng, P.; Mottram, P.; Curiel, T.; Lange, A.; Zou, W. Plasmacytoid dendritic cells induce CD8+ regulatory T cells in human ovarian carcinoma. Cancer Res. 2005, 65, 5020-5026. [CrossRef]

148. Dummer, R.; Urosevic, M.; Kempf, W.; Hoek, K.; Hafner, J.; Burg, G. Imiquimod in basal cell carcinoma: how does it work? Br. J. Dermatol. 2003, 149, 57-58. [CrossRef]

149. Tyring, S. Imiquimod applied topically: a novel immune response modifier. Skin Ther. Lett. 2001, 6, 1-4. 
150. Hofmann, M.A.; Kors, C.; Audring, H.; Walden, P.; Sterry, W.; Trefzer, U. Phase 1 evaluation of intralesionally injected TLR9-agonist PF-3512676 in patients with basal cell carcinoma or metastatic melanoma. J. Immunother. 2008, 31, 520-527. [CrossRef]

151. Lou, Y.; Liu, C.; Kim, G.J.; Liu, Y.-J.; Hwu, P.; Wang, G. Plasmacytoid dendritic cells synergize with myeloid dendritic cells in the induction of antigen-specific antitumor immune responses. J. Immunol. 2007, 178, 1534-1541. [CrossRef]

152. Piccioli, D.; Sammicheli, C.; Tavarini, S.; Nuti, S.; Frigimelica, E.; Manetti, A.G.; Nuccitelli, A.; Aprea, S.; Valentini, S.; Borgogni, E. Human plasmacytoid dendritic cells are unresponsive to bacterial stimulation and require a novel type of cooperation with myeloid dendritic cells for maturation. Blood 2009, 113, 4232-4239. [CrossRef] [PubMed]

153. Komai-Koma, M.; Jones, L.; Ogg, G.S.; Xu, D.; Liew, F.Y. TLR2 is expressed on activated T cells as a costimulatory receptor. Proc. Natl. Acad. Sci. USA 2004, 101, 3029-3034. [CrossRef] [PubMed]

154. Lu, H.; Yang, Y.; Gad, E.; Wenner, C.A.; Chang, A.; Larson, E.R.; Dang, Y.; Martzen, M.; Standish, L.J.; Disis, M.L. Polysaccharide krestin is a novel TLR2 agonist that mediates inhibition of tumor growth via stimulation of CD8 T cells and NK cells. Clin. Cancer Res. 2010, 17, 67-76. [CrossRef] [PubMed]

155. Zhang, Y.; Luo, F.; Cai, Y.; Liu, N.; Wang, L.; Xu, D.; Chu, Y. TLR1/TLR2 agonist induces tumor regression by reciprocal modulation of effector and regulatory T cells. J. Immunol. 2011, 186, 1963-1969. [CrossRef] [PubMed]

156. Geng, D.; Zheng, L.; Srivastava, R.; Asprodites, N.; Velasco-Gonzalez, C.; Davila, E. When toll-like receptor and T-cell receptor signals collide: a mechanism for enhanced CD8 T-cell effectors function. Blood 2010, 116, 3494-3504. [CrossRef]

157. Geng, D.; Zheng, L.; Srivastava, R.; Riker, A.I.; Velasco-Gonzales, C.; Markovic, S.N.; Davila, E. Amplifying TLR-MyD88 signals within tumor-specific T-cells enhances antitumor activity to suboptimal levels of weakly-immunogenic tumor-antigens. Cancer Res. 2010, 70, 7442-7454. [CrossRef]

158. Seki, E.; Tsutsui, H.; Tsuji, N.M.; Hayashi, N.; Adachi, K.; Nakano, H.; Futatsugi-Yumikura, S.; Takeuchi, O.; Hoshino, K.; Akira, S. Critical roles of myeloid differentiation factor 88-dependent proinflammatory cytokine release in early phase clearance of Listeria monocytogenes in mice. J. Immunol. 2002, 169, 3863-3868. [CrossRef]

159. Seki, E.; Brenner, D.A. Toll-like receptors and adaptor molecules in liver disease: update. Hepatology 2008, 48, 322-335. [CrossRef]

160. Zanin-Zhorov, A.; Nussbaum, G.; Franitza, S.; Cohen, I.R.; Lider, O. T cells respond to heat shock protein 60 via TLR2: activation of adhesion and inhibition of chemokine receptors. FASEB J. 2003, 17, 1567-1569. [CrossRef]

161. Mueller, K.L.; Daniels, M.A.; Felthauser, A.; Kao, C.; Jameson, S.C.; Shimizu, Y. Cutting edge: LFA-1 integrin-dependent $\mathrm{T}$ cell adhesion is regulated by both ag specificity and sensitivity. J. Immunol. 2004, 173, 2222-2226. [CrossRef]

162. Kobayashi, N.; Takata, H.; Yokota, S.; Takiguchi, M. Down-regulation of CXCR4 expression on human CD8+ T cells during peripheral differentiation. Eur. J. Immunol. 2004, 34, 3370-3378. [CrossRef]

163. Liu, H.; Komai-Koma, M.; Xu, D.; Liew, F.Y. Toll-like receptor 2 signaling modulates the functions of CD4+ CD25+ regulatory T cells. Proc. Natl. Acad. Sci. USA 2006, 103, 7048-7053. [CrossRef] [PubMed]

164. Rahman, A.H.; Taylor, D.K.; Turka, L.A. The contribution of direct TLR signaling to T cell responses. Immunol. Res. 2009, 45, 25-36. [CrossRef]

165. Salem, M.L. Triggering of toll-like receptor signaling pathways in T cells contributes to the anti-tumor efficacy of T cell responses. Immunol. Lett. 2011, 137, 9-14. [CrossRef]

166. Sutmuller, R.P.; den Brok, M.H.; Kramer, M.; Bennink, E.J.; Toonen, L.W.; Kullberg, B.-J.; Joosten, L.A.; Akira, S.; Netea, M.G.; Adema, G.J. Toll-like receptor 2 controls expansion and function of regulatory T cells. J. Clin. Invest. 2006, 116, 485-494. [CrossRef] [PubMed]

167. Rosenberg, S.A. Progress in human tumour immunology and immunotherapy. Nature 2001, 411, 380. [CrossRef]

168. Rosenberg, S.A.; Yang, J.C.; Restifo, N.P. Cancer immunotherapy: moving beyond current vaccines. Nat. Med. 2004, 10, 909. [CrossRef] 
169. Mercier, B.C.; Cottalorda, A.; Coupet, C.-A.; Marvel, J.; Bonnefoy-Bérard, N. TLR2 engagement on CD8 T cells enables generation of functional memory cells in response to a suboptimal TCR signal. J. Immunol. 2009, 182, 1860-1867. [CrossRef] [PubMed]

170. Kaech, S.M.; Tan, J.T.; Wherry, E.J.; Konieczny, B.T.; Surh, C.D.; Ahmed, R. Selective expression of the interleukin 7 receptor identifies effector CD8 T cells that give rise to long-lived memory cells. Nat. Immunol. 2003, 4, 1191. [CrossRef] [PubMed]

171. Zhu, X.-M.; Yao, Y.-M.; Liang, H.-P.; Xu, C.-T.; Dong, N.; Yu, Y.; Sheng, Z.-Y. High mobility group box-1 protein regulate immunosuppression of regulatory $\mathrm{T}$ cells through toll-like receptor 4. Cytokine 2011, 54, 296-304. [CrossRef]

172. Day, E.B.; Zeng, W.; Doherty, P.C.; Jackson, D.C.; Kedzierska, K.; Turner, S.J. The context of epitope presentation can influence functional quality of recalled influenza A virus-specific memory CD8+ T cells. J. Immunol. 2007, 179, 2187-2194. [CrossRef] [PubMed]

173. Deetz, C.O.; Hebbeler, A.M.; Propp, N.A.; Cairo, C.; Tikhonov, I.; Pauza, C.D. Gamma interferon secretion by human $\mathrm{V} \gamma 2 \mathrm{~V} \delta 2 \mathrm{~T}$ cells after stimulation with antibody against the T-cell receptor plus the Toll-Like receptor 2 agonist Pam3Cys. Infect. Immun. 2006, 74, 4505-4511. [CrossRef] [PubMed]

174. Lancioni, C.L.; Li, Q.; Thomas, J.J.; Ding, X.; Thiel, B.; Drage, M.G.; Pecora, N.D.; Ziady, A.G.; Shank, S.; Harding, C.V. Mycobacterium tuberculosis lipoproteins directly regulate human memory CD4+ T cell activation via Toll-like receptors 1 and 2. Infect. Immun. 2011, 79, 663-673. [CrossRef] [PubMed]

175. Gelman, A.E.; Zhang, J.; Choi, Y.; Turka, L.A. Toll-like receptor ligands directly promote activated CD4+ T cell survival. J. Immunol. 2004, 172, 6065-6073. [CrossRef]

176. Tabiasco, J.; Devêvre, E.; Rufer, N.; Salaun, B.; Cerottini, J.-C.; Speiser, D.; Romero, P. Human effector CD8+ T lymphocytes express TLR3 as a functional coreceptor. J. Immunol. 2006, 177, 8708-8713. [CrossRef]

177. Salem, M.L.; Diaz-Montero, C.M.; El-Naggar, S.A.; Chen, Y.; Moussa, O.; Cole, D.J. The TLR3 agonist poly (I: C) targets CD8+ T cells and augments their antigen-specific responses upon their adoptive transfer into naive recipient mice. Vaccine 2009, 27, 549-557. [CrossRef]

178. Wesch, D.; Beetz, S.; Oberg, H.-H.; Marget, M.; Krengel, K.; Kabelitz, D. Direct costimulatory effect of TLR3 ligand poly (I: C) on human $\gamma \delta \mathrm{T}$ lymphocytes. J. Immunol. 2006, 176, 1348-1354. [CrossRef]

179. Shojaei, H.; Oberg, H.-H.; Juricke, M.; Marischen, L.; Kunz, M.; Mundhenke, C.; Gieseler, F.; Kabelitz, D.; Wesch, D. Toll-like receptors 3 and 7 agonists enhance tumor cell lysis by human $\gamma \delta \mathrm{T}$ cells. Cancer Res. 2009, 0008-5472, CAN-0009-1602.

180. Alexopoulou, L.; Holt, A.C.; Medzhitov, R.; Flavell, R.A. Recognition of double-stranded RNA and activation of NF-kB by Toll-like receptor 3. Nature 2001, 413, 732-738. [CrossRef]

181. Doyle, S.E.; O'Connell, R.; Vaidya, S.A.; Chow, E.K.; Yee, K.; Cheng, G. Toll-like receptor 3 mediates a more potent antiviral response than Toll-like receptor 4. J. Immunol. 2003, 170, 3565-3571. [CrossRef]

182. Davey, G.M.; Wojtasiak, M.; Proietto, A.I.; Carbone, F.R.; Heath, W.R.; Bedoui, S. Cutting edge: priming of CD8 $\mathrm{T}$ cell immunity to herpes simplex virus type 1 requires cognate TLR3 expression in vivo. J. Immunol. 2010, 184, 2243-2246. [CrossRef] [PubMed]

183. Yadav, R.; Zammit, D.J.; Lefrancois, L.; Vella, A.T. Effects of LPS-mediated bystander activation in the innate immune system. J. Leukoc. Biol. 2006, 80, 1251-1261. [CrossRef] [PubMed]

184. Vogel, S.; Hilfiker, M.; Caulfield, M. Endotoxin-induced T lymphocyte proliferation. J. Immunol. 1983, 130, 1774-1779.

185. Komai-Koma, M.; Gilchrist, D.S.; Xu, D. Direct recognition of LPS by human but not murine CD8+ T cells via TLR4 complex. Eur. J. Immunol. 2009, 39, 1564-1572. [CrossRef] [PubMed]

186. Reynolds, J.M.; Martinez, G.J.; Chung, Y.; Dong, C. Toll-like receptor 4 signaling in T cells promotes autoimmune inflammation. Proc. Natl. Acad. Sci. USA 2012, 109, 13064-13069. [CrossRef] [PubMed]

187. Reynolds, J.M.; Pappu, B.P.; Peng, J.; Martinez, G.J.; Zhang, Y.; Chung, Y.; Ma, L.; Yang, X.O.; Nurieva, R.I.; Tian, Q. Toll-like receptor 2 signaling in CD4+ T lymphocytes promotes T helper 17 responses and regulates the pathogenesis of autoimmune disease. Immunity 2010, 32, 692-702. [CrossRef] [PubMed]

188. González-Navajas, J.M.; Fine, S.; Law, J.; Datta, S.K.; Nguyen, K.P.; Yu, M.; Corr, M.; Katakura, K.; Eckman, L.; Lee, J. TLR4 signaling in effector CD4+ T cells regulates TCR activation and experimental colitis in mice. J. Clin. Invest. 2010, 120, 570-581. [CrossRef] 
189. Caramalho, I.; Lopes-Carvalho, T.; Ostler, D.; Zelenay, S.; Haury, M.; Demengeot, J. Regulatory T cells selectively express toll-like receptors and are activated by lipopolysaccharide. J. Exp. Med. 2003, 197, 403-411. [CrossRef]

190. Caron, G.; Duluc, D.; Frémaux, I.; Jeannin, P.; David, C.; Gascan, H.; Delneste, Y. Direct stimulation of human T cells via TLR5 and TLR7/8: flagellin and R-848 up-regulate proliferation and IFN- $\gamma$ production by memory CD4+ T cells. J. Immunol. 2005, 175, 1551-1557. [CrossRef]

191. Crellin, N.K.; Garcia, R.V.; Hadisfar, O.; Allan, S.E.; Steiner, T.S.; Levings, M.K. Human CD4+ T cells express TLR5 and its ligand flagellin enhances the suppressive capacity and expression of FOXP3 in CD4+ CD25+ T regulatory cells. J. Immunol. 2005, 175, 8051-8059. [CrossRef]

192. Peng, G.; Guo, Z.; Kiniwa, Y.; shin Voo, K.; Peng, W.; Fu, T.; Wang, D.Y.; Li, Y.; Wang, H.Y.; Wang, R.-F. Toll-like receptor 8-mediated reversal of CD4+ regulatory T cell function. Science 2005, 309, 1380-1384. [CrossRef] [PubMed]

193. Peng, G.; Wang, H.Y.; Peng, W.; Kiniwa, Y.; Seo, K.H.; Wang, R.-F. Tumor-infiltrating $\gamma \delta$ T cells suppress $\mathrm{T}$ and dendritic cell function via mechanisms controlled by a unique toll-like receptor signaling pathway. Immunity 2007, 27, 334-348. [CrossRef] [PubMed]

194. Marsland, B.J.; Nembrini, C.; Grün, K.; Reissmann, R.; Kurrer, M.; Leipner, C.; Kopf, M. TLR ligands act directly upon $\mathrm{T}$ cells to restore proliferation in the absence of protein kinase $\mathrm{C}-\theta$ signaling and promote autoimmune myocarditis. J. Immunol. 2007, 178, 3466-3473. [CrossRef] [PubMed]

195. Chiffoleau, E.; Heslan, J.-M.; Heslan, M.; Louvet, C.; Condamine, T.; Cuturi, M.-C. TLR9 ligand enhances proliferation of rat CD4+ T cell and modulates suppressive activity mediated by CD4+ CD25+ T cell. Int. Immunol. 2007, 19, 193-201. [CrossRef] [PubMed]

196. Bendigs, S.; Salzer, U.; Lipford, G.B.; Wagner, H.; Heeg, K. CpG-oligodeoxynucleotides co-stimulate primary T cells in the absence of antigen-presenting cells. Eur. J. Immunol. 1999, 29, 1209-1218. [CrossRef]

197. Zheng, L.; Asprodites, N.; Keene, A.H.; Rodriguez, P.; Brown, K.D.; Davila, E. TLR9 engagement on CD4 T lymphocytes represses $\gamma$-radiation-induced apoptosis through activation of checkpoint kinase response elements. Blood 2008, 111, 2704-2713. [CrossRef]

198. Curtin, J.F.; Liu, N.; Candolfi, M.; Xiong, W.; Assi, H.; Yagiz, K.; Edwards, M.R.; Michelsen, K.S.; Kroeger, K.M.; Liu, C. HMGB1 mediates endogenous TLR2 activation and brain tumor regression. PLoS Med. 2009, 6, e1000010. [CrossRef]

199. Ribeiro, R.A.; Wanderley, C.W.; Wong, D.V.; Mota, J.M.S.; Leite, C.A.; Souza, M.H.; Cunha, F.Q.; Lima-Junior, R.C. Irinotecan-and 5-fluorouracil-induced intestinal mucositis: insights into pathogenesis and therapeutic perspectives. Cancer Chemother. Pharmacol. 2016, 78, 881-893. [CrossRef]

200. Kuo, W.-T.; Lee, T.-C.; Yu, L.C.-H. Eritoran suppresses colon cancer by altering a functional balance in Toll-like receptors that bind lipopolysaccharide. Cancer Res. 2016, 76, 4684-4695. [CrossRef]

201. Prakash, H.; Nadella, V.; Singh, S.; Schmitz-Winnenthal, H. CD14/TLR4 priming potentially recalibrates and exerts anti-tumor efficacy in tumor associated macrophages in a mouse model of pancreatic carcinoma. Sci. Rep. 2016, 6, 31490. [CrossRef]

202. Llitjos, J.F.; Auffray, C.; Alby-Laurent, F.; Rousseau, C.; Merdji, H.; Bonilla, N.; Toubiana, J.; Belaïdouni, N.; Mira, J.P.; Lucas, B. Sepsis-induced expansion of granulocytic myeloid-derived suppressor cells promotes tumour growth through Toll-like receptor 4. J. Pathol. 2016, 239, 473-483. [CrossRef] [PubMed]

203. Fukata, M.; Chen, A.; Vamadevan, A.S.; Cohen, J.; Breglio, K.; Krishnareddy, S.; Hsu, D.; Xu, R.; Harpaz, N.; Dannenberg, A.J. Toll-like receptor-4 promotes the development of colitis-associated colorectal tumors. Gastroenterology 2007, 133, 1869-1869. e1814. [CrossRef] [PubMed]

204. Furrie, E.; Macfarlane, S.; Thomson, G.; Macfarlane, G.T.; Microbiology, T.T.; Gut Biology Group; Bank, T. Toll-like receptors-2,-3 and-4 expression patterns on human colon and their regulation by mucosal-associated bacteria. Immunology 2005, 115, 565-574. [CrossRef]

205. Zhou, M.; McFarland-Mancini, M.M.; Funk, H.M.; Husseinzadeh, N.; Mounajjed, T.; Drew, A.F. Toll-like receptor expression in normal ovary and ovarian tumors. Cancer Immunol. Immunother. 2009, 58, 1375-1385. [CrossRef] [PubMed]

206. Kelly, M.G.; Alvero, A.B.; Chen, R.; Silasi, D.-A.; Abrahams, V.M.; Chan, S.; Visintin, I.; Rutherford, T.; Mor, G. TLR-4 signaling promotes tumor growth and paclitaxel chemoresistance in ovarian cancer. Cancer Res. 2006, 66, 3859-3868. [CrossRef] [PubMed] 
207. Chang, Y.-J.; Wu, M.-S.; Lin, J.-T.; Chen, C.-C. Helicobacter pylori-induced invasion and angiogenesis of gastric cells is mediated by cyclooxygenase-2 induction through TLR2/TLR9 and promoter regulation. $J$. Immunol. 2005, 175, 8242-8252. [CrossRef] [PubMed]

208. Niedzielska, I.; Orawczyk, T.; Ziaja, K.; Tkacz, M.; Starzewski, J.; Ciopala, M.; Kalacinski, J.; Niedzielski, Z.; Mazurek, U.; Ziaja, D. Toll-like receptors and the tendency of normal mucous membrane to transform to polyp or colorectal cancer. Int. J. Oral Maxillofac. Surg. 2009, 38, 574. [CrossRef]

209. Naugler, W.E.; Sakurai, T.; Kim, S.; Maeda, S.; Kim, K.; Elsharkawy, A.M.; Karin, M. Gender disparity in liver cancer due to sex differences in MyD88-dependent IL-6 production. Science 2007, 317, 121-124. [CrossRef]

210. Harmey, J.H.; Bucana, C.D.; Lu, W.; Byrne, A.M.; McDonnell, S.; Lynch, C.; Bouchier-Hayes, D.; Dong, Z. Lipopolysaccharide-induced metastatic growth is associated with increased angiogenesis, vascular permeability and tumor cell invasion. Int. J. Cancer 2002, 101, 415-422. [CrossRef]

211. Yang, H.; Zhou, H.; Feng, P.; Zhou, X.; Wen, H.; Xie, X.; Shen, H.; Zhu, X. Reduced expression of Toll-like receptor 4 inhibits human breast cancer cells proliferation and inflammatory cytokines secretion. J. Exp. Clin. Cancer Res. 2010, 29, 92. [CrossRef]

212. Bhattacharya, D.; Yusuf, N. Expression of toll-like receptors on breast tumors: taking a toll on tumor microenvironment. Int. J. Breast Cancer 2012, 2012. [CrossRef] [PubMed]

213. Huang, B.; Zhao, J.; Li, H.; He, K.-L.; Chen, Y.; Mayer, L.; Unkeless, J.C.; Xiong, H. Toll-like receptors on tumor cells facilitate evasion of immune surveillance. Cancer Res. 2005, 65, 5009-5014. [CrossRef] [PubMed]

214. Song, E.-J.; Kang, M.-J.; Kim, Y.-S.; Kim, S.-M.; Lee, S.-E.; Kim, C.-H.; Kim, D.-J.; Park, J.-H. Flagellin promotes the proliferation of gastric cancer cells via the Toll-like receptor 5. Int. J. Mol. Med. 2011, 28, 115-119.

215. Husseinzadeh, N.; Davenport, S.M. Role of toll-like receptors in cervical, endometrial and ovarian cancers: a review. Gynecol. Oncol. 2014, 135, 359-363. [CrossRef] [PubMed]

216. Cherfils-Vicini, J.; Platonova, S.; Gillard, M.; Laurans, L.; Validire, P.; Caliandro, R.; Magdeleinat, P.; Mami-Chouaib, F.; Dieu-Nosjean, M.-C.; Fridman, W.-H. Triggering of TLR7 and TLR8 expressed by human lung cancer cells induces cell survival and chemoresistance. J. Clin. Invest. 2010, 120, 1285-1297. [CrossRef] [PubMed]

217. Belmont, L.; Rabbe, N.; Antoine, M.; Cathelin, D.; Guignabert, C.; Kurie, J.; Cadranel, J.; Wislez, M. Expression of TLR9 in tumor-infiltrating mononuclear cells enhances angiogenesis and is associated with a worse survival in lung cancer. Int. J. Cancer 2014, 134, 765-777. [CrossRef]

218. Luo, Y.; Jiang, Q.-W.; Wu, J.-Y.; Qiu, J.-G.; Zhang, W.-J.; Mei, X.-L.; Shi, Z.; Di, J.-M. Regulation of migration and invasion by Toll-like receptor-9 signaling network in prostate cancer. Oncotarget 2015, 6, 22564. [CrossRef]

219. Bevers, R.; Kurth, K.; Schamhart, D. Role of urothelial cells in BCG immunotherapy for superficial bladder cancer. Br. J. Cancer 2004, 91, 607. [CrossRef]

220. Paone, A.; Starace, D.; Galli, R.; Padula, F.; De Cesaris, P.; Filippini, A.; Ziparo, E.; Riccioli, A. Toll-like receptor 3 triggers apoptosis of human prostate cancer cells through a PKC- $\alpha$-dependent mechanism. Carcinogenesis 2008, 29, 1334-1342. [CrossRef]

221. Taura, M.; Fukuda, R.; Suico, M.A.; Eguma, A.; Koga, T.; Shuto, T.; Sato, T.; Morino-Koga, S.; Kai, H. TLR3 induction by anticancer drugs potentiates poly I: C-induced tumor cell apoptosis. Cancer Sci. 2010, 101, 1610-1617. [CrossRef]

222. Salaun, B.; Lebecque, S.; Matikainen, S.; Rimoldi, D.; Romero, P. Toll-like receptor 3 expressed by melanoma cells as a target for therapy? Clin. Cancer Res. 2007, 13, 4565-4574. [CrossRef] [PubMed]

223. Bauer, A.K.; Dixon, D.; DeGraff, L.M.; Cho, H.-Y.; Walker, C.R.; Malkinson, A.M.; Kleeberger, S.R. Toll-like receptor 4 in butylated hydroxytoluene-induced mouse pulmonary inflammation and tumorigenesis. J. Natl. Cancer Inst. 2005, 97, 1778-1781. [CrossRef] [PubMed]

224. Cai, Z.; Sanchez, A.; Shi, Z.; Zhang, T.; Liu, M.; Zhang, D. Activation of Toll-like receptor 5 on breast cancer cells by flagellin suppresses cell proliferation and tumor growth. Cancer Res. 2011, 71, 2466-2475. [CrossRef] [PubMed]

225. Burdelya, L.G.; Gleiberman, A.S.; Toshkov, I.; Aygun-Sunar, S.; Bapardekar, M.; Manderscheid-Kern, P.; Bellnier, D.; Krivokrysenko, V.I.; Feinstein, E.; Gudkov, A.V. Toll-like receptor 5 agonist protects mice from dermatitis and oral mucositis caused by local radiation: implications for head-and-neck cancer radiotherapy. Int. J. Radiat. Oncol. Biol. Physics 2012, 83, 228-234. [CrossRef] 
226. Li, X.; Liu, D.; Liu, X.; Jiang, W.; Zhou, W.; Yan, W.; Cen, Y.; Li, B.; Cao, G.; Ding, G. CpG ODN107 potentiates radiosensitivity of human glioma cells via TLR9-mediated NF-KB activation and NO production. Tumor Biol. 2012, 33, 1607-1618. [CrossRef]

227. Damiano, V.; Rosa, R.; Formisano, L.; Nappi, L.; Gelardi, T.; Marciano, R.; Cozzolino, I.; Troncone, G.; Agrawal, S.; Veneziani, B. Toll-like receptor 9 agonist IMO cooperates with everolimus in renal cell carcinoma by interfering with tumour growth and angiogenesis. Br. J. Cancer 2013, 108, 1616. [CrossRef]

228. Guha, M. Anticancer TLR agonists on the ropes. Nat. Rev. Drug Discov. 2012, 11, 503-505. [CrossRef]

229. Chefetz, I.; Alvero, A.; Holmberg, J.; Lebowitz, N.; Craveiro, V.; Yang-Hartwich, Y.; Yin, G.; Squillace, L.; Gurrea Soteras, M.; Aldo, P. TLR2 enhances ovarian cancer stem cell self-renewal and promotes tumor repair and recurrence. Cell Cycle 2013, 12, 511-521. [CrossRef]

230. Kim, S.; Takahashi, H.; Lin, W.-W.; Descargues, P.; Grivennikov, S.; Kim, Y.; Luo, J.-L.; Karin, M. Carcinoma-produced factors activate myeloid cells through TLR2 to stimulate metastasis. Nature 2009, 457, 102. [CrossRef]

231. Li, D.; Wang, X.; Wu, J.-L.; Quan, W.-Q.; Ma, L.; Yang, F.; Wu, K.-Y.; Wan, H.-Y. Tumor-produced versican V1 enhances hCAP18/LL-37 expression in macrophages through activation of TLR2 and vitamin D3 signaling to promote ovarian cancer progression in vitro. PLoS One 2013, 8, e56616. [CrossRef]

232. Xie, W.; Wang, Y.; Huang, Y.; Yang, H.; Wang, J.; Hu, Z. Toll-like receptor 2 mediates invasion via activating NF-kB in MDA-MB-231 breast cancer cells. Biochem. Biophys. Res. Commun. 2009, 379, 1027-1032. [CrossRef]

233. Boraska Jelavić, T.; Barišić, M.; Drmic Hofman, I.; Boraska, V.; Vrdoljak, E.; Peruzović, M.; Hozo, I.; Puljiz, Ž.; Terzić, J. Microsatelite GT polymorphism in the toll-like receptor 2 is associated with colorectal cancer. Clin. Genet. 2006, 70, 156-160. [CrossRef]

234. Theodoropoulos, G.E.; Saridakis, V.; Karantanos, T.; Michalopoulos, N.V.; Zagouri, F.; Kontogianni, P.; Lymperi, M.; Gazouli, M.; Zografos, G.C. Toll-like receptors gene polymorphisms may confer increased susceptibility to breast cancer development. Breast 2012, 21, 534-538. [CrossRef] [PubMed]

235. Tomomitsu, T.; Tomiyasu, A.; Fangyu, W.; Tomoyuki, S.; Masakatsu, N.; Mikijyu, S.; Ichiro, H.; Hiroshi, N. Toll-like receptor $2-196$ to 174 del polymorphism influences the susceptibility of Japanese people to gastric cancer. Cancer Sci. 2007, 98, 1790-1794. [CrossRef]

236. Hans-Dieter, N.; Martin, C.; Cordula, B.; Katharina, A.; Tobias, M.; Thomas, B.; Benjamin, K.; Christian, K.; Margarete, O.; Falko, S.; et al. The toll-like receptor 2 (TLR2) -196 to -174 del/ins polymorphism affects viral loads and susceptibility to hepatocellular carcinoma in chronic hepatitis C. Int. J. Cancer 2012, 130, 1470-1475. [CrossRef]

237. Xie, W.; Huang, Y.; Xie, W.; Guo, A.; Wu, W. Bacteria Peptidoglycan Promoted Breast Cancer Cell Invasiveness and Adhesiveness by Targeting Toll-Like Receptor 2 in the Cancer Cells. PLoS One 2010, 5, e10850. [CrossRef]

238. He, W.; Liu, Q.; Wang, L.; Chen, W.; Li, N.; Cao, X. TLR4 signaling promotes immune escape of human lung cancer cells by inducing immunosuppressive cytokines and apoptosis resistance. Mol. Immunol. 2007, 44, 2850-2859. [CrossRef]

239. Szajnik, M.; Szczepanski, M.J.; Czystowska, M.; Elishaev, E.; Mandapathil, M.; Nowak-Markwitz, E.; Spaczynski, M.; Whiteside, T.L. TLR4 signaling induced by lipopolysaccharide or paclitaxel regulates tumor survival and chemoresistance in ovarian cancer. Oncogene 2009, 28, 4353. [CrossRef]

240. Hsu, R.Y.; Chan, C.H.; Spicer, J.D.; Rousseau, M.C.; Giannias, B.; Rousseau, S.; Ferri, L.E. LPS-induced TLR4 signaling in human colorectal cancer cells increases $\beta 1$ integrin-mediated cell adhesion and liver metastasis. Cancer Res. 2011, 71, 1989-1998. [CrossRef]

241. Yuan, X.; Zhou, Y.; Wang, W.; Li, J.; Xie, G.; Zhao, Y.; Xu, D.; Shen, L. Activation of TLR4 signaling promotes gastric cancer progression by inducing mitochondrial ROS production. Cell Death Dis. 2013, 4, e794. [CrossRef]

242. Liu, X.; Pei, C.; Yan, S.; Liu, G.; Liu, G.; Chen, W.; Cui, Y.; Liu, Y. NADPH oxidase 1-dependent ROS is crucial for TLR4 signaling to promote tumor metastasis of non-small cell lung cancer. Tumor Biol. 2015, 36, 1493-1502. [CrossRef] [PubMed]

243. Ikebe, M.; Kitaura, Y.; Nakamura, M.; Tanaka, H.; Yamasaki, A.; Nagai, S.; Wada, J.; Yanai, K.; Koga, K.; Sato, N. Lipopolysaccharide (LPS) increases the invasive ability of pancreatic cancer cells through the TLR4/MyD88 signaling pathway. J. Surg. Oncol. 2009, 100, 725-731. [CrossRef] [PubMed]

244. Sfondrini, L.; Rossini, A.; Besusso, D.; Merlo, A.; Tagliabue, E.; Mènard, S.; Balsari, A. Antitumor activity of the TLR-5 ligand flagellin in mouse models of cancer. J. Immunol. 2006, 176, 6624-6630. [CrossRef] [PubMed] 
245. Chatterjee, S.; Crozet, L.; Damotte, D.; Iribarren, K.; Schramm, C.; Alifano, M.; Lupo, A.; Cherfils-Vicini, J.; Goc, J.; Katsahian, S. TLR7 promotes tumor progression, chemotherapy resistance, and poor clinical outcomes in non-small cell lung cancer. Cancer Res. 2014, 74, 5008-5018. [CrossRef]

246. Grimmig, T.; Matthes, N.; Hoeland, K.; Tripathi, S.; Chandraker, A.; Grimm, M.; Moench, R.; Moll, E.-M.; Friess, H.; Tsaur, I. TLR7 and TLR8 expression increases tumor cell proliferation and promotes chemoresistance in human pancreatic cancer. Int. J. Oncol. 2015, 47, 857-866. [CrossRef]

247. Ren, T.; Wen, Z.-K.; Liu, Z.-M.; Liang, Y.-J.; Guo, Z.-L.; Xu, L. Functional expression of TLR9 is associated to the metastatic potential of human lung cancer cell. Cancer Biol. Ther. 2007, 6, 1704-1709. [CrossRef]

248. Ren, T.; Xu, L.; Jiao, S.; Wang, Y.; Cai, Y.; Liang, Y.; Zhou, Y.; Zhou, H.; Wen, Z. TLR9 signaling promotes tumor progression of human lung cancer cell in vivo. Pathol. Oncol. Res. 2009, 15, 623-630. [CrossRef]

249. Moreira, D.; Zhang, Q.; Hossain, D.M.S.; Nechaev, S.; Li, H.; Kowolik, C.M.; D'Apuzzo, M.; Forman, S.; Jones, J.; Pal, S.K. TLR9 signaling through NF-kB/RELA and STAT3 promotes tumor-propagating potential of prostate cancer cells. Oncotarget 2015, 6, 17302. [CrossRef]

250. Ilvesaro, J.M.; Merrell, M.A.; Swain, T.M.; Davidson, J.; Zayzafoon, M.; Harris, K.W.; Selander, K.S. Toll like receptor-9 agonists stimulate prostate cancer invasion in vitro. Prostate 2007, 67, 774-781. [CrossRef]

251. Xin, C.; Zhang, H.; Liu, Z. miR-154 suppresses colorectal cancer cell growth and motility by targeting TLR2. Mol. Cell. Biochem. 2014, 387, 271-277. [CrossRef]

252. Salaun, B.; Coste, I.; Rissoan, M.-C.; Lebecque, S.J.; Renno, T. TLR3 can directly trigger apoptosis in human cancer cells. J. Immunol. 2006, 176, 4894-4901. [CrossRef] [PubMed]

253. Harashima, N.; Inao, T.; Imamura, R.; Okano, S.; Suda, T.; Harada, M. Roles of the PI3K/Akt pathway and autophagy in TLR3 signaling-induced apoptosis and growth arrest of human prostate cancer cells. Cancer Immunol. Immunother. 2012, 61, 667-676. [CrossRef] [PubMed]

254. Fang, H.; Ang, B.; Xu, X.; Huang, X.; Wu, Y.; Sun, Y.; Wang, W.; Li, N.; Cao, X.; Wan, T. TLR4 is essential for dendritic cell activation and anti-tumor T-cell response enhancement by DAMPs released from chemically stressed cancer cells. Cell. Mol. Immunol. 2014, 11, 150. [CrossRef] [PubMed]

255. Kim, J.Y.; Kim, Y.J.; Kim, J.S.; Ryu, H.S.; Lee, H.K.; Kang, J.S.; Kim, H.M.; Hong, J.T.; Kim, Y.; Han, S.-B. Adjuvant effect of a natural TLR4 ligand on dendritic cell-based cancer immunotherapy. Cancer Lett. 2011, 313, 226-234. [CrossRef] [PubMed]

256. Nguyen, C.T.; Hong, S.H.; Sin, J.-I.; Vu, H.V.D.; Jeong, K.; Cho, K.O.; Uematsu, S.; Akira, S.; Lee, S.E.; Rhee, J.H. Flagellin enhances tumor-specific CD8+ T cell immune responses through TLR5 stimulation in a therapeutic cancer vaccine model. Vaccine 2013, 31, 3879-3887. [CrossRef]

257. Shi, M.; Yao, Y.; Han, F.; Li, Y.; Li, Y. MAP1S controls breast cancer cell TLR5 signaling pathway and promotes TLR5 signaling-based tumor suppression. PloS One 2014, 9, e86839. [CrossRef]

258. Zhou, H.; Chen, J.-h.; Hu, J.; Luo, Y.-z.; Li, F.; Xiao, L.; Zhong, M.-z. High expression of Toll-like receptor 5 correlates with better prognosis in non-small-cell lung cancer: an anti-tumor effect of TLR5 signaling in non-small cell lung cancer. J. Cancer Res. Clin. Oncol. 2014, 140, 633-643. [CrossRef]

259. Spinetti, T.; Spagnuolo, L.; Mottas, I.; Secondini, C.; Treinies, M.; Rüegg, C.; Hotz, C.; Bourquin, C. TLR7-based cancer immunotherapy decreases intratumoral myeloid-derived suppressor cells and blocks their immunosuppressive function. Oncoimmunology 2016, 5, e1230578. [CrossRef]

260. Ito, H.; Ando, T.; Ogiso, H.; Arioka, Y.; Seishima, M. Inhibition of induced nitric oxide synthase enhances the anti-tumor effects on cancer immunotherapy using TLR7 agonist in mice. Cancer Immunol. Immunother. 2015, 64, 429-436. [CrossRef]

261. Brignole, C.; Marimpietri, D.; Di Paolo, D.; Perri, P.; Morandi, F.; Pastorino, F.; Zorzoli, A.; Pagnan, G.; Loi, M.; Caffa, I. Therapeutic targeting of TLR9 inhibits cell growth and induces apoptosis in neuroblastoma. Cancer Res. 2010, 70, 9816-9826. [CrossRef]

262. Pashenkov, M.; Goëss, G.; Wagner, C.; Hörmann, M.; Jandl, T.; Moser, A.; Britten, C.M.; Smolle, J.; Koller, S.; Mauch, C. Phase II trial of a Toll-like receptor 9-activating oligonucleotide in patients with metastatic melanoma. J. Clin. Oncol. 2006, 24, 5716-5724. [CrossRef] [PubMed]

263. Galluzzi, L.; Vacchelli, E.; Eggermont, A.; Fridman, W.H.; Galon, J.; Sautès-Fridman, C.; Tartour, E.; Zitvogel, L.; Kroemer, G. Trial Watch: Experimental Toll-like receptor agonists for cancer therapy. Oncoimmunology 2012, 1, 699-739. [CrossRef] [PubMed] 
264. Bekierkunst, A.; Levij, I.; Yarkoni, E.; Vilkas, E.; Lederer, E. Suppression of urethan-induced lung adenomas in mice treated with trehalose-6, 6-dimycolate (cord factor) and living bacillus Calmette Guérin. Science 1971, 174, 1240-1242. [CrossRef] [PubMed]

265. Sjögren, H.O.; Ankerst, J. Effect of BCG and allogeneic tumour cells on adenovirus type 12 tumorigenesis in mice. Nature 1969, 221, 863-864. [CrossRef]

266. Zbar, B.; Bernstein, I.; Tanaka, T.; Rapp, H.J. Tumor immunity produced by the intradermal inoculation of living tumor cells and living Mycobacterium bovis (strain BCG). Science 1970, 170, 1217-1218. [CrossRef]

267. Zbar, B.; Tanaka, T. Immunotherapy of cancer: regression of tumors after intralesional injection of living Mycobacterium bovis. Science 1971, 271-273. [CrossRef]

268. Morales, A.; Eidinger, D.; Bruce, A. Intracavitary Bacillus Calmette-Guerin in the treatment of superficial bladder tumors. J. Urol. 1976, 116, 180-182. [CrossRef]

269. Hall, M.C.; Chang, S.S.; Dalbagni, G.; Pruthi, R.S.; Seigne, J.D.; Skinner, E.C.; Wolf, J.S.; Schellhammer, P.F. Guideline for the management of nonmuscle invasive bladder cancer (stages Ta, T1, and Tis): 2007 update. J. Urol. 2007, 178, 2314-2330. [CrossRef]

270. Babjuk, M.; Oosterlinck, W.; Sylvester, R.; Kaasinen, E.; Böhle, A.; Palou-Redorta, J.; Rouprêt, M. EAU guidelines on non-muscle-invasive urothelial carcinoma of the bladder, the 2011 update. Eur. Urol. 2011, 59, 997-1008. [CrossRef]

271. Kroemer, G.; Zitvogel, L.; Galluzzi, L. Victories and Deceptions in Tumor Immunology: Stimuvax@; Taylor \& Francis: Milton, UK, 2013.

272. Chin, A.I.; Miyahira, A.K.; Covarrubias, A.; Teague, J.; Guo, B.; Dempsey, P.W.; Cheng, G. Toll-like receptor 3-mediated suppression of TRAMP prostate cancer shows the critical role of type I interferons in tumor immune surveillance. Cancer Res. 2010, 70, 2595-2603. [CrossRef]

273. Forte, G.; Rega, A.; Morello, S.; Luciano, A.; Arra, C.; Pinto, A.; Sorrentino, R. Polyinosinic-polycytidylic acid limits tumor outgrowth in a mouse model of metastatic lung cancer. J. Immunol. 2012, 188, 5357-5364. [CrossRef] [PubMed]

274. Garaude, J.; Kent, A.; van Rooijen, N.; Blander, J.M. Simultaneous targeting of toll-and nod-like receptors induces effective tumor-specific immune responses. Sci. Transl. Med. 2012, 4, ra116-ra120. [CrossRef] [PubMed]

275. Burdelya, L.G.; Krivokrysenko, V.I.; Tallant, T.C.; Strom, E.; Gleiberman, A.S.; Gupta, D.; Kurnasov, O.V.; Fort, F.L.; Osterman, A.L.; DiDonato, J.A. An agonist of toll-like receptor 5 has radioprotective activity in mouse and primate models. Science 2008, 320, 226-230. [CrossRef] [PubMed]

276. Lan, T.; Kandimalla, E.R.; Yu, D.; Bhagat, L.; Li, Y.; Wang, D.; Zhu, F.; Tang, J.X.; Putta, M.R.; Cong, Y. Stabilized immune modulatory RNA compounds as agonists of Toll-like receptors 7 and 8. Proc. Natl. Acad. Sci. USA 2007, 104, 13750-13755. [CrossRef]

277. Geisse, J.; Caro, I.; Lindholm, J.; Golitz, L.; Stampone, P.; Owens, M. Imiquimod 5\% cream for the treatment of superficial basal cell carcinoma: results from two phase III, randomized, vehicle-controlled studies. J. Am. Acad. Dermatol. 2004, 50, 722-733. [CrossRef]

278. Love, W.E.; Bernhard, J.D.; Bordeaux, J.S. Topical imiquimod or fluorouracil therapy for basal and squamous cell carcinoma: a systematic review. Arch. Dermatol. 2009, 145, 1431-1438. [CrossRef]

279. Rajpar, S.; Marsden, J. Imiquimod in the treatment of lentigo maligna. Br. J. Dermatol. 2006, 155, 653-656. [CrossRef]

280. Krieg, A.M. Development of TLR9 agonists for cancer therapy. J. Clin. Invest. 2007, 117, 1184-1194. [CrossRef]

281. Baines, J.; Celis, E. Immune-mediated tumor regression induced by CpG-containing oligodeoxynucleotides. Clin. Cancer Res. 2003, 9, 2693-2700.

282. Carpentier, A.F.; Chen, L.; Maltonti, F.; Delattre, J.-Y. Oligodeoxynucleotides containing CpG motifs can induce rejection of a neuroblastoma in mice. Cancer Res. 1999, 59, 5429-5432.

283. Heckelsmiller, K.; Rall, K.; Beck, S.; Schlamp, A.; Seiderer, J.; Jahrsdörfer, B.; Krug, A.; Rothenfusser, S.; Endres, S.; Hartmann, G. Peritumoral CpG DNA elicits a coordinated response of CD8 T cells and innate effectors to cure established tumors in a murine colon carcinoma model. J. Immunol. 2002, 169, 3892-3899. [CrossRef]

284. Goutagny, N.; Estornes, Y.; Hasan, U.; Lebecque, S.; Caux, C. Targeting pattern recognition receptors in cancer immunotherapy. Target. Oncol. 2012, 7, 29-54. [CrossRef] 
285. Kolida, S.; Gibson, G.R. Synbiotics in health and disease. Annu. Rev. Food Sci. Technol. 2011, 2, $373-393$. [CrossRef] [PubMed]

286. Le Leu, R.K.; Hu, Y.; Brown, I.L.; Woodman, R.J.; Young, G.P. Synbiotic intervention of Bifidobacterium lactis and resistant starch protects against colorectal cancer development in rats. Carcinogenesis 2009, 31, 246-251. [CrossRef] [PubMed]

287. Rowland, I.; Rumney, C.; Coutts, J.; Lievense, L. Effect of Bifidobacterium longum and inulin on gut bacterial metabolism and carcinogen-induced aberrant crypt foci in rats. Carcinogenesis 1998, 19, 281-285. [CrossRef] [PubMed]

288. Zhang, H.-L.; Yu, L.-X.; Yang, W.; Tang, L.; Lin, Y.; Wu, H.; Zhai, B.; Tan, Y.-X.; Shan, L.; Liu, Q. Profound impact of gut homeostasis on chemically-induced pro-tumorigenic inflammation and hepatocarcinogenesis in rats. J. Hepatol. 2012, 57, 803-812. [CrossRef]

289. Grivennikov, S.I.; Wang, K.; Mucida, D.; Stewart, C.A.; Schnabl, B.; Jauch, D.; Taniguchi, K.; Yu, G.-Y.; Österreicher, C.H.; Hung, K.E. Adenoma-linked barrier defects and microbial products drive IL-23/IL-17-mediated tumour growth. Nature 2012, 491, 254. [CrossRef]

290. Couturier-Maillard, A.; Secher, T.; Rehman, A.; Normand, S.; De Arcangelis, A.; Haesler, R.; Huot, L.; Grandjean, T.; Bressenot, A.; Delanoye-Crespin, A. NOD2-mediated dysbiosis predisposes mice to transmissible colitis and colorectal cancer. J. Clin. Invest. 2013, 123, 700-711. [CrossRef]

291. Dapito, D.H.; Mencin, A.; Gwak, G.-Y.; Pradere, J.-P.; Jang, M.-K.; Mederacke, I.; Caviglia, J.M.; Khiabanian, H.; Adeyemi, A.; Bataller, R. Promotion of hepatocellular carcinoma by the intestinal microbiota and TLR4. Cancer Cell 2012, 21, 504-516. [CrossRef]

292. Yu, L.X.; Yan, H.X.; Liu, Q.; Yang, W.; Wu, H.P.; Dong, W.; Tang, L.; Lin, Y.; He, Y.Q.; Zou, S.S. Endotoxin accumulation prevents carcinogen-induced apoptosis and promotes liver tumorigenesis in rodents. Hepatology 2010, 52, 1322-1333. [CrossRef]

293. Bass, N.M.; Mullen, K.D.; Sanyal, A.; Poordad, F.; Neff, G.; Leevy, C.B.; Sigal, S.; Sheikh, M.Y.; Beavers, K.; Frederick, T. Rifaximin treatment in hepatic encephalopathy. N. Engl. J. Med. 2010, 362, 1071-1081. [CrossRef] [PubMed]

294. Fort, M.M.; Mozaffarian, A.; Stöver, A.G.; da Silva Correia, J.; Johnson, D.A.; Crane, R.T.; Ulevitch, R.J.; Persing, D.H.; Bielefeldt-Ohmann, H.; Probst, P. A synthetic TLR4 antagonist has anti-inflammatory effects in two murine models of inflammatory bowel disease. J. Immunol. 2005, 174, 6416-6423. [CrossRef] [PubMed]

295. Rossignol, D.P.; Lynn, M. Antagonism of in vivo and ex vivo response to endotoxin by E5564, a synthetic lipid A analogue. J. Endotoxin Res. 2002, 8, 483-488. [CrossRef] [PubMed]

296. Sha, T.; Sunamoto, M.; Kitazaki, T.; Sato, J.; Ii, M.; Iizawa, Y. Therapeutic effects of TAK-242, a novel selective Toll-like receptor 4 signal transduction inhibitor, in mouse endotoxin shock model. Eur. J. Pharmacol. 2007, 571, 231-239. [CrossRef] [PubMed]

297. Arslan, F.; Houtgraaf, J.H.; Keogh, B.; Kazemi, K.; de Jong, R.; McCormack, W.J.; O’Neill, L.A.; McGuirk, P.; Timmers, L.; Smeets, M.B. Treatment with OPN-305, a humanized anti-Toll-like receptor-2 antibody, reduces myocardial ischemia/reperfusion injury in pigs. Circ. Cardiovasc. Interv. 2012, 5, 279-287. [CrossRef]

298. Palucka, K.; Banchereau, J. Cancer immunotherapy via dendritic cells. Nat. Rev. Cancer 2012, $12,265$. [CrossRef]

(C) 2020 by the authors. Licensee MDPI, Basel, Switzerland. This article is an open access article distributed under the terms and conditions of the Creative Commons Attribution (CC BY) license (http://creativecommons.org/licenses/by/4.0/). 